\title{
PENGARUH LITERASI EKONOMI SISWA, HASIL BELAJAR EKONOMI, DAN TEMAN SEBAYA TERHADAP PERILAKU KONSUMSI SISWA SMP NEGERI DI SURABAYA BARAT
}

\author{
Endah Murniatiningsih, SMP Negeri 28 Surabaya \\ endahhwa@yahoo.co.id
}

\begin{abstract}
ABSTRAK
Penelitian ini bertujuan untuk menganalisis pengaruh literasi ekonomi siswa, hasil belajar ekonomi, dan teman sebaya terhadap perilaku konsumsi siswa SMP Negeri di Surabaya Wilayah Barat. Populasi penelitian ini adalah siswa SMP Negeri 28 Surabaya kelas VIII sebanyak 369 orang dan siswa SMP Negeri 40 Surabaya kelas VIII sebanyak 330 siswa, dengan jumlah sampel sebanyak 254 siswa. Adapun teknik pengumpulan data menggunakan angket dan dokumentasi. Metode analisis menggunakan teknik regresi linier berganda. Hasil penelitian menunjukkan bahwa literasi ekonomi siswa, hasil belajar ekonomi, dan teman sebaya secara parsial berpengaruh signifikan positif terhadap perilaku konsumsi. Literasi ekonomi siswa, hasil belajar ekonomi, dan teman sebaya secara simultan berpengaruh signifikan positif terhadap perilaku konsumsi siswa.

Kata Kunci: Literasi Ekonomi, Hasil Belajar, Teman Sebaya, Perilaku Konsumsi
\end{abstract}

\begin{abstract}
This study aimed to analyze the effect of the Students Economic Literacy, the results of the economic study, and peers on consumption behavior of students of SMP Negeri Surabaya Western Conference. The research population was students of SMP Negeri 28 Surabaya class VIII as many as 369 people and students of SMP Negeri 40 Surabaya class VIII as many as 330 students, with a total sample of 254 students. The data collection techniques using questionnaires and documentation. Methods of analysis using multiple linear regression techniques. The results showed that the students economic literacy, the results of the economic study, and peer partially has a positive and significant effect on consumption behavior. The students economic literacy of students, the results of the economic study, and peer simultaneously positive significant effect on consumption behavior of students.
\end{abstract}

Keywords: Economic Literacy, Learning Outcomes, Peers, Consumption Behavior.

\section{PENDAHULUAN}

Usaha manusia untuk memenuhi semua kebutuhan hidupnya yang salah satunya kita kenal dengan tindakan konsumsi telah mengalami perkembangan. Kebutuhan tersier yang bersifat sebagai hiburan, sekarang ini seperti 
menggantikan kebutuhan primer. Perilaku konsumsi manusia saat ini cenderung bukan didasari oleh kebutuhan melainkan berdasarkan keinginan semata, tidak peduli berapa biaya yang harus dikeluarkan asalkan dapat terpenuhi seperti yang mereka harapkan.

Namun dalam memenuhi kebutuhannya manusia dihadapkan pada masalah ekonomi yang berlaku sebagai akibat adanya ketidakseimbangan antara kebutuhan manusia yang tidak terbatas dengan alat pemuas kebutuhan yang jumlahnya terbatas atau yang disebut sebagai adanya kelangkaan. Banks (dalam Budiwati, 2014) mengemukakan: esensi konsep kelangkaan adalah bahwa keinginan manusia tidak terbatas, namun jumlah sumber-sumber daya dalam suatu masyarakat adalah terbatas. Permasalahan inilah yang menjadi penghalang manusia dalam mencapai tujuan hidupnya. Manusia terkadang tidak menyadari keterbatasan pendapatan yang dimilikinya sehingga berakibat pola konsumsi manusia tidak rasional, dikarenakan perilaku konsumsi manusia tidak didasarkan pada pertimbangan yang matang, melainkan atas dasar keinginan dan kesenangan semata (motivasi hedonis)

Perkembangan dan kemajuan jaman telah membawa dampak terhadap perkembangan sarana dan prasarana untuk berbelanja, hal ini dapat diwujudkan semakin maraknya mall, kafe, ataupun tempat perbelanjaan lainnya yang sekarang ini semakin menjamur keberadaannya. Masyarakat semakin dimanjakan dalam hal pemenuhan kebutuhan hidupnya, sehingga mengarah kepada tindakan konsumsi yang berlebihan atau yang disebut dengan gaya hidup konsumtif.

Begitu juga di wilayah Surabaya Barat, meskipun berada di pinggiran kota Surabaya, namun perkembangan kemajuan di wilayah tersebut sungguh pesat. Selain banyak kawasan perumahan elit juga terdapat pusat perbelanjaan (mall) yang terkenal yaitu Pakuwon Trade Center (PTC), kawasan G-Walk Citraland, dan berbagai restoran maupun kafe di lingkungan sekitarnya yang menyediakan berbagai tempat perbelanjaan, aneka kuliner, maupun sarana hiburan. Hampir setiap hari kawasan tersebut tidak pernah sepi pengunjung mulai dari masyarakat golongan bawah, menengah hingga golongan atas, tidak terkecuali para remaja atau usia ABG (anak baru gede). Kondisi ini secara tidak langsung mempengaruhi gaya konsumsi masyarakat menjadi tidak rasional.

Perilaku konsumsi yang tidak rasional ini tidak hanya dialami oleh manusia dewasa saja, namun juga melanda aktivitas ekonomi para siswa terutama dalam melakukan tindakan konsumsi. Seperti yang terjadi dalam aktivitas konsumsi para siswa SMP Negeri di Surabaya wilayah Barat. Fenomena yang terjadi menunjukkan seringkali siswa melakukan kesalahan dalam penggunaan uang sakunya. Penggunaan uang saku mereka sebagian besar hanya untuk pembelian barang-barang yang bersifat kesenangan saja tetapi tidak bermanfaat bagi kebutuhan siswa, misalnya menghabiskan sebagian besar uang saku untuk pembelian pulsa handphone, main game, jalanjalan, atau nonton bioskop dari pada untuk kebutuhan pokok lainnya yang lebih penting, misalnya untuk kebutuhan pelajaran.

Penggunaan akal sehat atau rasionalitas dalam berkonsumsi terkait dengan pendidikan seseorang. Pendidikan dapat melatih penggunaan akal sehat dalam meningkatkan pemahaman dan pengetahuan seseorang. Pengajaran 
materi ekonomi yang merupakan bagian dari Ilmu Pengetahuan Sosial kepada siswa SMP tidak hanya menekankan pada kemampuan kognitif saja, melainkan secara menyeluruh baik dari kemampuan psikomotor maupun sikap. Mata pelajaran ekonomi berfungsi membekali siswa dengan pengetahuan dan keterampilan dasar agar mampu mengambil keputusan secara rasional tindakan ekonomi dalam menentukan berbagai pilihan (Depdiknas 2001).

Dengan mempelajari ilmu ekonomi, diharapkan siswa dapat memiliki pemahaman dan penguasaan terhadap konsep-konsep dasar ekonomi atau yang disebut dengan literasi ekonomi. Literasi ekonomi menurut NCEE, adalah suatu kondisi yang menggambarkan seseorang dapat memahami permasalahan dasar ekonomi secara baik, sehingga dapat melakukan kegiatan ekonomi dengan benar (Daroin, 2010). Jadi literasi ekonomi sebagai salah satu alat indikator kompetensi pengetahuan ekonomi yang mempengaruhi kehidupan di segala bidang.

Berdasarkan data survey, literasi ekonomi para siswa SMP Negeri di Surabaya wilayah Barat masih tergolong rendah, hal ini dapat diketahui dari perilaku ekonomi mereka yang tidak rasional. Mereka sering terlihat menghabiskan waktu berjam-jam di kafe atau tempat nongkrong anak muda yang sering dikenal dengan in The Point. Mereka sering tidak menghabiskan makanan atau minuman yang mereka beli. Kurang produktif dalam arti mereka belum mampu memanfaatkan sumber daya yang mereka miliki dan yang terdapat di lingkungan sekitarnya untuk dapat memecahkan permasalahan ekonomi yang dihadapi sehari-hari, misalnya di tengah-tengah bergejolaknya kenaikan harga, mereka justru tidak mengindahkan sikap penghematan, akan tetapi justru malah semakin boros, ditambah lagi masih rendahnya minat untuk menabung di kalangan siswa.

Tinggi rendahnya tingkat pemahaman terhadap dasar-dasar ekonomi berarti juga menunjukkan tinggi rendahnya literasi ekonomi. Hal ini sejalan dengan hasil penelitian Yanti (2014) yang menemukan bahwa secara parsial penguasaan konsep ekonomi berpengaruh terhadap pola perilaku konsumsi siswa. Jika siswa memiliki pengetahuan dasar ekonomi yang baik, maka perilaku ekonominya akan semakin baik, dengan demikian akan semakin rasional pula pola perilaku konsumsinya, misalnya dalam membelanjakan uang saku siswa sehari-hari. Menurut Mathews (1999), bahwa manfaat mempelajari literasi ekonomi yakni antara lain menjadi penabung. Bahkan menurut pendapat Sina (2012) bahwa akibat dari pemahaman literasi ekonomi yang tidak memadai akan tampak dari bagaimana seseorang mengalami kesalahan ketika membuat keputusan pembelanjaan, fenomena lain masih menurutnya adalah rendahnya spirit masyarakat Indonesia untuk menabung dan kebiasaan belanja yang berlebihan sehingga sulit untuk menjadi konsumen yang cerdas.

Kemampuan seseorang dalam menentukan tindakan ekonomi yang rasional juga dapat diukur dari hasil belajar yang diperoleh dalam pembelajaran ekonomi. Menurut Mulyasa (2008), hasil belajar merupakan prestasi belajar siswa secara keseluruhan yang menjadi indikator kompetensi dan derajat perilaku yang bersangkutan. Kompetensi yang harus dikuasai siswa perlu dinyatakan sedemikian rupa agar dapat dinilai sebagai wujud hasil belajar siswa yang mengacu pada pengalaman langsung. 
Dalam proses belajar di lingkungan pendidikan formal, seseorang dibentuk dengan sedemikian rupa sehingga seseorang tersebut mampu dan cakap untuk mengatasi masalah-masalah dalam menjalani kehidupannya sesuai dengan tuntutan disiplin ilmu yang telah dipelajarinya dan menjadi dasar dalam bertindak atau berperilaku. Siswa yang hasil belajar IPS (Ekonomi)-nya baik tentu dapat menentukan tindakan konsumsinya berdasarkan pertimbangan yang rasional pula. Menurut hasil penelitian Purwati (2011), ditemukan bahwa prestasi belajar ekonomi siswa berpengaruh secara positif dan signifikan terhadap perilaku konsumsi siswa. Hal ini berarti siswa yang hasil belajar ekonominya baik, maka perilaku konsumsinya juga baik. Demikian juga dari hasil penelitian Hadija (2013) ditemukan bahwa secara parsial prestasi belajar ekonomi berpengaruh signifikan terhadap perilaku konsumsi siswa.

Berdasarkan hasil survey peserta didik tahun pelajaran 2014/2015 semester ganjil, peserta didik kelas VIII di SMP Negeri di Surabaya wilayah Barat, antara lain di SMP Negeri 28 Surabaya, dengan jumlah peserta didik 369 siswa, menunjukkan bahwa 23\% (85) siswa yang hasil ulangan harian ekonominya masih kurang dari kriteria ketuntasan minimal (KKM), sehingga harus mengikuti remidial, sedangkan di SMP Negeri 40 Surabaya dengan jumlah peserta didik 330 siswa, sebesar 27\% (89) siswa yang hasil nilai ulangan harian ekonominya masih di bawah KKM. Dimana nilai KKM yang sudah ditetapkan di masing-masing sekolah adalah tujuh puluh delapan (78). Sehingga hasil belajar pada mata pelajaran IPS materi ekonomi masih belum bisa mencapai hasil maksimal. Kondisi ini menunjukkan bahwa rata-rata siswa kelas VIII SMP Negeri di Surabaya wilayah Barat masih belum tuntas dalam mempelajari materi ekonomi yang telah disampaikan dalam proses pembelajaran. Meskipun demikian belum diketahui apakah hasil belajar ekonomi siswa tersebut berpengaruh atau tidak pada perilaku konsumsi siswa, serta mampu membentuk sikap sebagai pelaku ekonomi yang rasional berdasarkan pengalaman belajar yang diterimanya.

Selain faktor literasi ekonomi siswa dan hasil belajar ekonomi yang mempengaruhi perilaku konsumsi siswa, pergaulan dengan teman sebaya juga ikut berperan.Teman sebaya adalah lingkungan kedua setelah keluarga yang berpengaruh bagi kehidupan individu. Hal ini sejalan dengan pendapat Peter dan Olson (dalam Hadija, 2013) yang menyatakan bahwa selain ibu dan ayah, keputusan pembelian pada anak-anak dan orang dewasa keduanya sangat dipengaruhi oleh teman sebaya. Shaffer (2005), mendefinisikan teman sebaya atau peer group sebagai kelompok yang lebih memberikan pengaruh dalam memilih cara berpakaian, hobi, perkumpulan (club) dan kegiatan-kegiatan sosial lainnya.

Demikian juga yang terjadi dalam pergaulan siswa SMP Negeri di lingkungan Surabaya wilayah Barat menunjukkan indikasi adanya kecenderungan beberapa kelompok siswa sangat berpengaruh dalam pergaulan antar teman, antara lain dalam perilaku konsumsi. Sering terlihat beberapa kelompok remaja atau siswa jalan-jalan di mall, nongkrong di kafe sembari makan sambil ngobrol, ataupun main game di arena time zone. Apapun aktivitas mereka menunjukkan ciri khas suatu komunitas yang merupakan trend anak muda yang memiliki keseragaman, baik dalam penampilan mulai model rambut hingga gaya berpakaian, pemakaian atribut, hingga selera dalam 
mengkonsumsi makanan maupun minuman. Mereka seolah sudah terbuai dengan kesenangan atau hedonisme tanpa mempertimbangkan manfaat (utilitas) dari produk / jasa yang mereka beli.

Remaja sering dihadapkan pada penerimaan atau penolakan teman sebaya di dalam pergaulan. Untuk menghindari penolakan teman sebaya, maka remaja cenderung mengikuti hal-hal yang sama dengan kelompok sebaya agar diterima dengan baik di dalam kelompok sebaya (Mappiare, 1982), misalnya apabila salah satu teman membeli produk atau barang tertentu, maka teman yang lain juga ikut-ikutan membeli. Hoyer dan MacInnis (2008) juga menjelaskan bahwa ada kecenderungan bagi seorang individu untuk berperilaku sebagaimana kelompoknya berperilaku yang disebut dengan konformitas.

Konformitas terhadap pengaruh teman sebaya dapat berdampak positif dan negatif. Perilaku negatif ini karena para remaja mungkin menyesuaikan diri dengan tujuan menghindari untuk menjadi berbeda dari teman-temannya karena itu akan terlihat aneh, meskipun perilaku yang mereka tiru terkadang beresiko atau tidak sesuai dengan norma dan aturan, misalnya tindakan merokok, minum-minuman keras dan sebagainya. Menurut temuan Gardner dan Steinberg (2005), bahwa remaja lebih cenderung ke arah pengambilan keputusan dan perilaku berisiko daripada orang dewasa dan pengaruh teman sebaya memegang peranan penting dalam menjelaskan perilaku berisiko selama masa remaja. Gardner dan Steinberg menjelaskan usia remaja adalah pada kelompok umur 13 - 16 tahun, dimana siswa SMP pada umumnya berada pada rentang usia tersebut.

Terpengaruh tidaknya individu dengan teman sebaya tergantung pada persepsi individu terhadap kelompoknya, sebab persepsi individu terhadap kelompok sebayanya akan menentukan keputusan yang diambil nantinya. Laursen (2005) menandaskan bahwa teman sebaya merupakan faktor yang sangat berpengaruh terhadap kehidupan pada masa-masa remaja. Aktivitas pertemanan mereka juga tidak hanya melalui pertemuan secara fisik tetapi juga melalui jejaring sosial media, misalnya melalui facebook, twitter, instagram, whatsapp, line, dan sebagainya.

Melalui jejaring sosial media mereka dapat menjalin pertemanan dan saling berbagi informasi, bahkan transaksi bisnis seperti yang dikenal sebagai bisnis online. Menurut penelitian Ioanas dan Stoica (2014), jaringan sosial memiliki peran dalam mempengaruhi perilaku konsumen dalam lingkungan virtual, terutama ketika tingkat paparan dari pesan dan hubungan dibuat antara berbagai informasi yang diberikan dan konsumen yang akan membuat keputusan pembelian. Apabila salah satu anggota telah memiliki barang-barang tersebut, mereka sering kali menjadi sumber informasi bagi anggota lainnya.

Berdasarkan feomena di atas, maka penulis tertarik untuk melakukan penelitian dengan judul "Pengaruh literasi ekonomi siswa, hasil belajar ekonomi, dan teman sebaya terhadap perilaku konsumsi siswa SMP Negeri di Surabaya Wilayah Barat".

Konsumsi berasal dari bahasa Belanda consumptie, ialah suatu kegiatan yang bertujuan mengurangi atau menghabiskan daya guna suatu benda, baik berupa barang maupun jasa, untuk memenuhi kebutuhan dan kepuasan secara langsung. Adapun menurut ilmu ekonomi (Wibowo, 2013), konsumsi adalah 
setiap kegiatan memanfaatkan, menghabiskan kegunaan barang dan jasa untuk memenuhi kebutuhan dalam upaya menjaga kelangsungan hidup. Menurut Hananto dan Sukarto (Sukirno, 2002), konsumsi adalah bagian dari penghasilan yang dipergunakan membeli barang atau jasa untuk memenuhi kebutuhan hidup. Samuelsondan Nordhaus (2000) menjelaskan bahwa konsumsi adalah kegiatan menghabiskan utility (nilai guna) barang dan jasa.

Menurut Mowen dan Minor (2002), perilaku konsumsi didefinisikan sebagai studi tentang unit pembelian (buying units) dan proses pertukaran yang melibatkan perolehan, konsumsi dan pembuangan barang, jasa, pengalaman serta ide-ide. Sedangkan menurut Kotler (2007), mengatakan bahwa perilaku konsumsi merupakan studi tentang cara individu, kelompok, dan organisasi dalam menyeleksi, membeli, menggunakan, dan memposisikan barang, jasa, gagasan, atau pengalaman untuk memuaskan kebutuhan dan keinginan mereka.

Menurut Don Slater (Damsar, 2011), konsumsi adalah bagaimana manusia dengan kebutuhan yang dimilikinya berhubungan dengan sesuatu (dalam hal ini material, barang simbolik, jasa atau pengalaman) yang dapat memuaskan mereka. Pendapat Slater tersebut sesuai dengan istilah mengkonsumsi seperti yang dikutip Featherstone (2001) dari Raymond Williams, sebagai merusak (to destroy), memakai (to use up), membuang (to waste) dan menghabiskan (Damsar, 2009).

Perilaku konsumsi menurut Handoko (dalam Wulandari , 2011) tindakan yang langsung terlibat dalam mendapatkan, mengkonsumsi, dan menghabiskan suatu barang atau jasa termasuk proses keputusan yang mendahului dan mengikuti tindakan ini. Sedangkan menurut Mangkunegara (dalam Prasastianta, 2011), perilaku konsumsi merupakan proses pengambilan keputusan dalam menilai, mendapatkan, menggunakan atau mengabaikan barang-barang dan jasa-jasa sesuai kebutuhan. Sejalan dengan pendapat Mangkunegara, Sastradipora (dalam Wirawan, 2015) menyatakan bahwa perilaku konsumsi adalah proses dimana para individu menetapkan jawaban atas pertanyaan : perlukah, apakah, kapankah, dimanakah, bagaimanakah, dan dari siapakah membeli barang atau jasa. Dari beberapa pendapat ahli di atas, maka dapat disimpulkan bahwa perilaku konsumsi merupakan suatu proses dan tindakan-tindakan yang berkaitan dengan pemilihan, pembelian, dan pemanfaatan nilai guna barang atau jasa demi memenuhi kebutuhan.

Konsep ekonomi menunjukkan bahwa kebutuhan manusia itu sifatnya tidak terbatas, sedangkan alat pemuas kebutuhan terbatas atau bersifat langka. Oleh karena itu, sepanjang hidupnya manusia senantiasa harus berpikir, berusaha, memilih untuk dapat mengambil keputusan yang rasional dalam pembelian maupun pemanfaatan yang berupa menggunakan, mengurangi atau menghabiskan nilai kegunaan barang atau jasa demi terpenuhinya kebutuhan. Kerapkali manusia dalam melakukan tindakan konsumsi bukan atas dasar dorongan kebutuhan, melainkan karena dorongan kesenangan (motivasi hedonis). Motivasi hedonis menurut Arnold dan Reynolds (2003) merupakan suatu kegiatan pembelian yang didorong dengan perilaku yang berhubungan dengan panca indera, khayalan dan emosi yang menjadikan kesenangan dan kenikmatan materi sebagai tujuan utaman hidup.

Ada beberapa teori etika yang berkaitan dengan perilaku konsumenmenurut Burton F. Porter (1988), yait: (a) Hedonisme, bahwa 
kesenangan dan kebahagiaan merupakan tujuan dari hidup yang dijalani; (b) Utilitarianisme, suatu paham yang memiliki landasan moral untuk mencari kegunaan atau kebahagiaan terbesar; (c) Self-Realization, suatu teori yang memandang bahwa tujuan hidup ini adalah merupakan kesadaran penuh terhadap kemampuan pribadi yang dimiliki.

Perilaku konsumen dapat dilihat dari dua pendekatan (Sukirno, 2014), yaitu: (a) Pendekatan Nilai Guna Kardinal; (b) Pendekatan Nilai Guna Ordinal. Menurut pendekatan nilai guna kardinal, bahwa kepuasan seorang konsumen diukur dengan satuan kepuasan (misalnya uang). Setiap tambahan satu unit barang yang dikonsumsi akan menambah kepuasan yang diperoleh konsumen tersebut dalam jumlah tertentu. Sedangkan menurutpendekatan nilai guna ordinal, bahwa daya guna suatu barang tidak perlu diukur, cukup untuk diketahui dan konsumen mampu membuat urutan tinggi rendahnya daya guna yang diperoleh dari mengkonsumsi sekelompok barang.

Perilaku konsumen baik secara langsung maupun tidak langsung sangat dipengaruhi oleh beberapa faktor (Hadija, 2013) yaitu faktor intern (psikologis) dan faktor ekstern. Faktor intern meliputi: (a) Pengalaman belajar, bahwa belajar adalah suatu perubahan perilaku akibat pengalaman sebelumnya (Mangkunegara, 1988:48); (b) Kepribadian; (c) Sikap dan Keyakinan; (d) Usia; (e) Pekerjaan atau jabatan; (f) Ekonomi. Dilihat dari usia, siswa SMP termasuk golongan anak remaja awal, hal ini sesuai pendapat Monks, dkk (2000) memberi batasan usia remaja adalah $12-21$ tahun.

Ada perbedaan antara usia remaja dengan usia dewasa dalam kemampuan psikososial, bahwa usia dewasa lebih matang dalam mengambil keputusan pembelian, usia remaja cenderung mencari sensasi karena pengaruh rekan kelompoknya atau teman sebayanya, sehingga tindakannya seringkali penuh resiko (Cauffman \& Steinberg, 2000). Faktor ekstern meliputi: (a) Sosial Budaya; (b) Kelas Sosial; (c) Kelompok Rujukan; (d) Lingkungan Ekonomi. Kelas sosial meliputi golongan atas, yang memiliki kecenderungan membeli barang-barang mahal dan berkualitas, golongan menengah yang memiliki kecenderungan membeli barang dengan kualitas cukup memadai, dan golongan rendah, yang memiliki kecenderungan mementingkan kuantitas dari pada kualitasnya (Kotler \& Amstrong, 2006).

Menurut Schiffman dan Kanuk (2008) kelompok rujukan adalah setiap orang atau kelompok yang dianggap sebagai dasar perbandingan (atau rujukan) bagi seseorang dalam membentuk nilai-nilai dan sikap umum atau khusus, atau pedoman khusus bagi perilaku. Peter dan Olson (2010: 336) mengatakan bahwa sebagian besar riset konsumen fokus pada dua kelompok utama yaitu grup informal : teman sebaya dan keluarga. Pendapat ini sejalan dengan Schiffman \& Kanuk (2008: 292) kelompok rujukan bila ditinjau dari perspektif pemasaran merupakan kelompok yang menjadi acuan bagi individu dalam melakukan pengambilan keputusan pembelian mereka.

Pengaruh kelompok rujukan terhadap konsumen diantaranya dijelaskan oleh Peter dan Olson (2010) bahwa kelompok rujukan tidak hanya mempengaruhi pengetahuan konsumen, perilaku dan nilai-nilai tetapi juga mempengaruhi pembelian produk dan merk yang spesifik, bahkan pemilihan toko dimana pembelian akan dilakukan.Kelompok yang punya pengaruh langsung terhadap seseorang disebut kelompok primer, misalnya keluarga, 
kawan dan tetangga. Sedang kelompok yang berinteraksi secara formal yaitu kelompok sekunder, misalnya organisasi sosial, keagamaan, dan organisasi profesi.

Salah satu teori motivasi kebutuhan manusia adalah teori hirarki kebutuhan yang diciptakan oleh Abraham Maslow (dalam Suwatno, 2011). Dalam teorinya mengatakan bahwa manusia memiliki lima tingkat kebutuhan mulai dari paling bawah sampai paling tinggi. Manusia terlebih dahulu akan memenuhi kebutuhan yang paling bawah sebelum berusaha untuk memenuhi kebutuhan yang paling tinggi. Kelima kebutuhan tersebut adalah sebagai berikut :Physiological needs, Safety needs, Social needs, Esteem needs, dan Self actualization.

Pada prinsipnya seorang konsumen dalam melakukan tindakan konsumsi selalu bersikap rasional. Hal ini dikarenakan asumsi klasik bahwa manusia adalah homoeconomicus, artinya manusia sebagai makhluk ekonomi yang rasional. Menurut Robbins dan Judge (2008), bahwa rasional adalah membuat pilihan-pilihan yang konsisten dan memaksimalkan nilai dalam batasanbatasan tertentu.

Adapun indikator yang digunakan dalam mengukur perilaku konsumsi siswa sebagai berikut: (a) Pemenuhan kebutuhan sesuai intensitas; (b) Motif melakukan konsumsi; (c) Penerapan prinsip ekonomi dalam berkonsumsi. Dalam pemenuhan kebutuhan sesuai intensitas, menurut Abraham Maslow (dalam Suwatno, 2011) dalam teorinya mengatakan bahwa manusia memiliki lima tingkat kebutuhan mulai dari paling bawah (dasar) sampai paling tinggi. Manusia terlebih dahulu akan memenuhi kebutuhan yang paling bawah sebelum berusaha untuk memenuhi kebutuhan yang paling tinggi. Kebutuhan dasar atau yang disebut kebutuhan fisiologis, misalnya makanan, tempat tinggal, sandang.

Sedangkan indikator motif melakukan konsumsi dalam memenuhi kebutuhan menurut Abraham Maslow (dalam Suwatno, 2011), antara lain : motif sosial; motif penghargaan; motif aktualisas diri. Dalam hal penerapan prinsip ekonomi dalam berkonsumsi menurut Raharjo (2008) menyatakan, prinsip ekonomi merupakan pedoman atau patokan yang digunakan manusia dalam melakukan kegiatan tindakan ekonomi. Pedoman tersebut berupa, "Dengan pengorbanan yang sekecil-kecilnya untuk memperoleh hasil tertentu atau dengan pengorbanan tertentu untuk memperoleh hasil yang maksimal".

Perilaku konsumen yang rasional sebelum membeli dan mengkonsumsi barang atau jasa akan melakukan perhitungan secara matang dan memaksimalkan nilai gunanya. Indikator alat ukurnya adalah : memperhatikan manfaat atas barang atau jasa; mempertimbangkan harga dan kualitas barang/jasa; memperhatikan kemampuan daya beli; mengembangkan sikap hemat.

Literasi Ekonomi atau yang disebut Economic Literacy berasal dari bahasa Inggris, jika dipilah menurut arti sesungguhnya, economic berarti ilmu ekonomi dan literacy berarti melek, jadi economic literacy dapat diartikan melek ekonomi. Melek berdasarkan bahasa dapat menangkap atau memahami apa yang dimaksud oleh sesuatu. Sosialisasi literasi ekonomi pertama kali diperkenalkan oleh Dewan Nasional Pendidikan Ekonomi Amerika Serikat atau lebih dikenal dengan NCEE (The National Council on Economic 
Education). Menurut NCEE (2005), bahwa literasi ekonomi adalah suatu kondisi yang menggambarkan seseorang dapat memahami permasalahan dasar ekonomi secara baik, sehingga dapat melakukan kegiatan ekonomi dengan benar". (Daroin, 2010).

Sedangkan North Central Regional Educational Laboratory atau NCREL (dalam Nuray Mercan dkk, 2014) mengartikan bahwa literasi ekonomi adalah kemampuan menafsirkan masalah ekonomi dan memeriksa pilihan yang berbeda yang berkaitan dengan mencari solusi, mendefinisikan biaya dan keuntungan, menganalisis hasil dari perubahan kondisi ekonomi dan kebijakan publik, mengumpulkan dan mengorganisir data, menimbang biaya dan keuntungan. Jadi pendidikan literasi ekonomi adalah suatu proses yang meningkatkan pemahaman konsep dan risiko konsumen atau investor melalui menginformasikan, instruksi dan / atau rekomendasi yang obyektif; mengembangkan kemampuan dan kepercayaan yang diperlukan untuk menyadari risiko keuangan dan peluang, membuat pilihan sadar, tahu kemana harus berkonsultasi untuk bantuan dan melakukan tindakan-tindakan lain dengan tujuan memperbaiki kondisi keuangan mereka (OECD dalam Mercan, dkk,2014).

Literasi ekonomi tidak dapat dipisahkan dari pembelajaran ekonomi. Pembentukan sikap dan perilaku ekonomi siswa merupakan tujuan yang harus dicapai dalam setiap pembelajaran ekonomi. Pembentukan sikap ini dapat ditempuh melalui pendidikan formal maupun informal. Pembentukan sikap dan perilaku ekonomi secara formal dapat ditempuh melalui proses pembelajaran yang terjadi di sekolah dengan bantuan atau bimbingan guru bidang studi khususnya ilmu ekonomi.

Dengan demikian sikap ekonomi secara formal dapat dibentuk melalui proses pembelajaran khususnya ilmu ekonomi. Hal ini sejalan dengan pendapat Bimo Walgito (1994) yang menyatakan bahwa perilaku yang dominan adalah perilaku yang dibentuk, diperoleh serta dipelajari melalui proses pembelajaran. Dengan demikian jika siswa telah belajar konsep-konsep ekonomi, maka akan dapat mendorong siswa untuk berperilaku yang rasional.

Menurut pendapat Caplan (dalam Januar Kustiandi, 2011) yang menyatakan bahwa literasi ekonomi merupakan pengetahuan tentang ekonomi yang hal ini sangat diperlukan karena setiap kegiatan manusia tidak terlepas dari masalah ekonomi. Masalah-masalah ekonomi ini berkaitan dengan bagaimana seseorang dapat memanfaatkan keterbatasan sumber daya yang dimiliki untuk dapat menentukan pilihan alternatif pemecahan masalah yang tepat dalam memenuhi kebutuhan hidupnya, dengan mempertimbangkan antara pengorbanan biaya dengan hasil (manfaat) yang akan diperoleh. Hal ini sejalan dengan pendapat Haryono (2008), bahwa literasi ekonomi adalah kemampuan untuk mengidentifikasi masalah-masalah ekonomi, penyusunanan alternatif pemecahan dengan mempertimbangkan benefit dan cost.

Sejalan dengan pendapat Haryono, Peter Sina (2012), mengatakan bahwa literasi ekonomi merupakan pemahaman seseorang yang terkristalkan dalam membuat pilihan yang cerdas terkait alokasi sumber daya. Dengan demikian literasi ekonomi dapat membantu seseorang untuk dapat memecahkan permasalahan ekonomi melalui pengambilan keputusan secara tepat, seperti yang diungkapkan oleh Wulandari (2011), bahwa literasi ekonomi adalah 
keterampilan hidup (life skill) yang harus dimiliki oleh siapa saja untuk membuat keputusan ekonomi yang tepat.

Sedangkan menurut Mathews (1999) bahwa literasi ekonomi sebagai kemampuan individu untuk mengenali dan menggunakan konsep-konsep ekonomi dan cara berpikir ekonomi untuk memperbaiki dan mendapatkan kesejahteraan. Seperti yang diungkapkan dalam teori Salemi (2005) yang menjelaskan bahwa siswa mencapai literasi ekonomi jika mereka dapat menerapkan konsep dasar ekonomi pada tahun-tahun kemudian, dalam situasi yang relevan dengan kehidupan mereka dan berbeda dari yang dihadapi di kelas.

Literasi ekonomi juga dapat menumbuhkan minat siswa untuk menabung. Seperti hasil temuan dalam penelitian Yunus, dkk (2010) bahwa literasi ekonomi berhubungan positif dengan niat menabung. Hal ini sesuai dengan pendapat Mattews dalam Sina (2012) bahwa manfaat mempelajari literasi ekonomi yakni antara lain menjadi penabung. Demikian juga menurut Wulandari (2011) menegaskan bahwa literasi ekonomi meliputi kemampuan dan kesadaran individu tentang apa, mengapa dan bagaimana menjadi konsumen cerdas, produsen bijak, penabung dan investor, pekerja produktif dan warga negara yang bertanggung jawab.

Indikator literasi ekonomi yang digunakan dalam penelitian ini mengacu pada teori literasi ekonomi menurut NCEE (Daroin, 2010), bahwa literasi ekonomi adalah suatu kondisi yang menggambarkan seseorang dapat memahami permasalahan dasar ekonomi secara baik, sehingga dapat melakukan kegiatan ekonomi dengan benar. Berdasarkan teori tersebut dan dihubungkan dengan konsep dasar materi ekonomi yang terdapat dalam materi IPS SMP kelas VII dan VIII, maka indikator literasi ekonomi yang digunakan dalam penelitian ini mengacu pada indikator literasi ekonomi menurut NCEE (2005) sebagai berikut: (a) Mampu menjelaskan pendapatan individu; (b)Mampu menjelaskan penggunaan sumber daya yang terbatas; (c) Mampu menganalisis cost dan benefit dari transaksi ekonomi; (d) Mampu menganalisis cost dan benefit dari pengambilan keputusan.

Implementasi dari belajar adalah hasil belajar. Hasil belajar diperoleh pada akhir proses pembelajaran dan berkaitan dengan kemampuan siswa dalam menyerap atau memahami suatu bahan yang diajarkan. Kemampuan siswa dalam menyerap atau memahami suatu bahan yang telah diajarkan dapat diketahui berdasarkan penilaian yang dilakukan oleh guru.

Sukmadinata (2007) mengatakan bahwa hasil belajar merupakan realisasi atau pemekaran dari kecakapan-kecakapan potensial atau kapasitas yang dimiliki seseorang. Kamus Umum Bahasa Indonesia oleh Poerwodarminto (1990) menyatakan bahwa, "Hasil belajar ekonomi adalah pengukuran pengetahuan atau keterampilan yang dikembangkan oleh mata pelajaran, lazimnya ditunjukkan dengan nilai atau angka yang diberikan oleh guru. Sedangkan menurut Suryabrata (2002) hasil belajar ekonomi sebagai nilai yang merupakan bentuk perumusan akhir yang diberikan oleh guru terkait dengan kemajuan atau hasil belajar ekonomi siswa selama waktu tertentu..

Menurut Suharsimi Arikunto (2000), hasil belajar adalah hasil yang dicapai seseorang setelah melakukan kegiatan belajar. Hasil belajar ini merupakan penilaian yang dicapai seorang siswa untuk mengetahui sejauh 
mana bahan pelajaran atau materi yang diajarkan dapat dipahami siswa. Untuk dapat menentukan tercapai atau tidaknya tujuan pembelajaran dilakukan usaha untuk menilai hasil belajar. Penilaian ini bertujuan untuk melihat kemajuan peserta didik dalam menguasai materi yang telah dipelajari dan ditetapkan.

Menurut Dimyati dan Mudjiono (2006), hasil belajar adalah hasil yang dicapai dalam bentuk angka-angka atau skor setelah diberikan tes hasil belajar pada setiap akhir pembelajaran. Nilai yang diperoleh siswa menjadi acuan untuk melihat penguasaan siswa dalam menerima materi pembelajaran. Lebih lanjut, menurut Hamalik (2008), hasil belajar adalah sebagai terjadinya perubahan tingkah laku pada diri seseorang yang dapat diamati dan diukur bentuk pengetahuan, sikap dan keterampilan. Perubahan tersebut dapat diartikan sebagai terjadinya peningkatan dan pengembangan yang lebih baik sebelumnya yang tidak tahu menjadi tahu.

Sedangkan menurut Mulyasa (2008), hasil belajar merupakan prestasi belajar siswa secara keseluruhan yang menjadi indikator kompetensi dan derajat perilaku yang bersangkutan. Kompetensi yang harus dikuasai siswa perlu dinyatakan sedemikian rupa agar dapat dinilai sebagai wujud hasil belajar siswa yang mengacu pada pengalaman langsung. Sukiman (2012) menjelaskan bahwa berdasarkan Taksonomi Bloom, hasil belajar dalam rangka studi dicapai melalui tiga kategori ranah antara lain kognitif, afektif, psikomotor.

Berdasarkan beberapa definisi hasil belajar di atas, dapat disimpulkan bahwa hasil belajar merupakan hasil yang diperoleh siswa setelah terjadinya proses pembelajaran yang ditunjukkan dengan nilai tes yang merupakan gambaran umum mengenai besarnya tingkat penguasaan dan pemahaman siswa terhadap materi pelajaran pada satu pokok bahasan. Faktor- faktor yang mempengaruhi hasil belajar menurut Munadi (dalam Rusman, 2012) antara lain meliputi faktor internal dan eksternal. Faktor Internal meliputi faktor fisiologis dan faktor psikologis, sedangkan faktor eksternal meliputi faktor lingkungan dan faktor instrumentalia.

Indikator yang digunakan dalam mengukur hasil belajar adalah menggunakan instrumen berupa dokumentasi tentang hasil nilai ulangan harian. Ulangan harian adalah kegiatan yang dilakukan secara periodik untuk mengukur pencapaian kompetensi peserta didik setelah menyelesaikan satu Kompetensi Dasar atau lebih. Nilai ulangan harian yang dijadikan alat ukur pada penelitian ini adalah nilai ulangan hariansiswa pada mata pelajaran IPS materi ekonomi kelas VIII semester genap dengan tema III : Fungsi dan peran sumber daya alam dalam pembangunan nasional, sub-sub tema C.1 Fungsi dan peran sumber daya alam dalam pembangunan ekonomi.

Teman sebaya menurut Santrock (2007) adalah anak-anak atau remaja yang memiliki usia atau tingkat kematangan yang kurang lebih sama. Sependapat dengan Santrock, Hartup (Santrock, 2003) mengungkapkan bahwa teman sebaya (peers) adalah anak-anak atau remaja dengan tingkat usia atau tingkat kedewasaan yang sama. Interaksi teman sebaya dengan usia yang sama memainkan peran yang unik pada kehidupan remaja. Sedangkan menurut Chaplin (2001) kelompok teman sebaya (peer group) merupakan kelompok yang terdiri dari teman seusianya dan mereka dapat mengasosiasikan dirinya.

Willis (2005) menambahkan selain umur atau usia yang sama, teman sebaya adalah sekelompok anak atau remaja yang memiliki motivasi bergaul 
yang sama. Menurut Brown (dalam Ryan, 2001) mengungkapkan pengertian kelompok teman sebaya adalah segala bentuk interaksi anak atau remaja dengan teman karib sepermainan yang memiliki tingkat usia, minat dan tujuan yang sama. Teman sebaya menurut Shaffer (2005), mendefinisikan teman sebaya atau peer group sebagai kelompok yang lebih memberikan pengaruh dalam memilih cara berpakaian, hobi, perkumpulan (club) dan kegiatankegiatan sosial lainnya. Steinberg (dalam Ryan, 2001) mengkonseptualisasikan kelompok teman sebaya atau klik adalah anak atau remaja yang memiliki dua sampai dua belas orang anggota kelompok yang rata-rata memiliki usia dan minat yang sama.

Berdasarkan beberapa definisi tentang kelompok teman sebaya yang dikemukakan oleh para ahli di atas, dapat disimpulkan bahwa peer groups adalah sekelompok teman sebaya yang mempunyai ikatan emosional yang kuat dan mereka dapat berinteraksi, bertukar pikiran, dan pengalaman dalam memberikan perubahan dan pengembangan dalam kehidupan sosial dan pribadinya.

Menurut Tirtahardja dan La Sula (2005), kelompok sebaya adalah suatu kelompok yang terdiri dari orang-orang yang bersamaan usianya, antara lain : kelompok bermain pada masa kanak-kanak, kelompok monoseksual yang hanya beranggotakan anak-anak sejenis kelamin, atau gang yaitu kelompok anak-anak nakal. Menurut Abu Ahmadi(2007), ada sejumlah unsur pokok dalam pengertian komunitas teman sebaya antara lain: (a) kelompok sebaya adalah kelompok primer yang berhubungan antar anggotanya intim; (b) anggota kelompok sebaya terdiri atas sejumlah individu yang mempunyai persamaan usia status atau posisi sosial; (c) Istilah kelompok sebaya dapat menunjukkan kelompok anak-anak, kelompok remaja dan kelompok orang dewasa.Maka dapat disimpulkan bahwa komunitas teman sebaya adalah lingkungan terjadinya interaksi yang aktif antar anggotanya yang merupakan anak-anak yang mempunyai umur relatif sama, minat yang sama dan aturan yang dibuat bersama-sama.

Menurut Azhari (2004) remaja atau adolescence berasal dari bahasa Latin dari kata adolenecentia yang berarti remaja yang dapat diartikan juga sebagai tumbuh atau tumbuh menjadi dewasa. Lebih lanjut Sarwono (2001) menggunakan batasan usia 11-14 tahun dan belum menikah untuk remaja Indonesia. Lewin (dalam Sarwono, 2001) dengan teorinya Psiko-dinamika menyatakan bahwa remaja memiliki tingkah laku yang gelisah dan meletupletup. Menurutnya salah satu tingkah laku yang akan selalu terdapat pada remaja diantaranya adalah remaja terus-menerus merasakan pertentangan antar sikap, nilai, ideologi dan gaya hidup. Remaja tidak punya tempat berpijak yang bisa memberinya rasa aman, kecuali dalam hubungannya dengan teman-teman sebayanya.

Sementara Ormrod (2008) mengungkapkan bahwa bagi sebagian besar remaja awal, penerimaan sosial dan penampilan fisik jauh lebih penting dibandingkan kompetensi akademis. Sejalan dengan pendapat di atas, Santrock (2002) menjelaskan tentang transisi ke masa remaja, bahwa plasma pembawa sifat (gen) yang diwariskan dari orang tua masih mempengaruhi pemikiran dan perilaku selama masa remaja, tetapi kini gen berinteraksi dengan kondisikondisi sosial dunia remaja dengan keluarga, teman-teman sebaya, 
persahabatan, dan pengalaman-pengalaman bersekolah. Dari berbagai pendapat di atas dapat disimpulkan bahwa masa remaja adalah masa peralihan atau masa transisi dari anak-anak menjadi dewasa, dimana dalam proses transisi tersebut terjadi perubahan dalam diri remaja secara fisik dan psikologinya. Remaja cenderung mementingkan penampilan fisik dan penerimaan sosial dari temanteman sebayanya.

Menurut Ormrod (2008) peran teman sebaya dalam perkembangan remaja antara lain, sebagai suatu medan pembelajaran dan pelatihan berbagai keterampilan sosial bagi para remaja, termasuk negosiasi, persuasi, kerjasama, kompromi, kendali emosional, dan penyelesaian konflik. Selain itu juga teman sebaya berperan dalam memberikan dukungan sosial dan emosional yang sangat dibutuhkan para remaja. Menurut pendapat Santrock (2007), mengatakan bahwa peran terpenting dari teman sebaya adalah a)sebagai sumber informasi mengenai dunia di luar keluarga; b) sumber kognitif, untuk pemecahan masalah dan perolehan pengetahuan; c) sumber emosional, untuk mengungkapkan ekspresi dan identitas diri. Dari uraian tersebut maka dapat diketahui bahwa teman sebaya sebagai lingkungan sosial bagi remaja mempunyai peranan yang cukup penting bagi perkembangan kepribadiannya.

Teman sebaya memberikan sebuah dunia tempat para remaja melakukan sosialisasi dalam suasana yang mereka ciptakan sendiri (Piaget dan Sullivan dalam Santrock, 2007). Menurut pendapat Selman \& Selman (dalam Sarwono, 2001) bahwa pengaruh lingkungan yang pertama adalah pergaulan dengan teman. Pada usia 9-15 tahun hubungan pertemanan adalah hubungan yang akrab dan diikat oleh minat yang sama, kepentingan bersama dan saling membagi perasaan, saling tolong-menolong untuk memecahkan masalah bersama. Dan pada usia 12 tahun ke atas, ikatan emosinya bertambah kuat dan mereka makin saling membutuhkan akan tetapi juga saling memberi kesempatan untuk mengembangkan kepribadiannya masing-masing.

Pendapat di atas sejalan dengan pendapat Schiffman dan Kanuk (2008) yang menyatakan bahwa :mencari dan memelihara persahabatan merupakan keinginan utama kebanyakan orang karena mereka mampu memberikan rasa aman, kebersamaan, dan kesempatan untuk membicarakan berbagai masalah yang enggan dibicarakan dengan keluarga. Dari segi pengaruh relatif sesudah keluarga, teman-teman yang paling mungkin mempengaruhi keputusan pembelian individu. Sejalan dengan pendapat Schiffman dan Kanuk, Peter dan Olson (2010) menyatakan bahwa selain ibu dan ayah, keputusan pembelian pada anak-anak dan orang dewasa keduanya sangat dipengaruhi oleh teman sebaya. Pendapat dan pilihan teman-teman merupakan pengaruh yang penting dalam menentukan produk atau merk yang akhirnya dipilih konsumen.

Hoyer dan MacInnis (2008) menjelaskan bahwa ada kecenderungan bagi seorang individu untuk berperilaku sebagaimana kelompoknya berperilaku atau "The tendency to behave in expected way"yang biasa disebut dengan konformitas. Santrock (2002) menjelaskan tentang tekanan teman sebaya dan tuntutan konformitas pada masa remaja dapat bersifat positif ataupun negatif, misalnya menggunakan bahasa yang jorok atau juga beresiko, seperti merokok, minum-minuman keras, mencuri.

Sejalan dengan pendapat Santrock, Ormrod (2008) mengemukakan bahwa teman sebaya dapat memberi pengaruh yang baik dan dapat juga 
memberi pengaruh yang buruk. Akan tetapi betapapun kuatnya pengaruh teman sebaya dalam kehidupan remaja, sebenarnya tekanan konformitas itu muncul dari dalam diri remaja itu sendiri yang disebut dengan self-socialization dan dengan pertimbangan baik buruk, serta evaluasi atas perilaku serta pengetahuan yang dimiliki remaja tersebut dari nilai-nilai dalam keluarga, nilai-nilai dan norma yang berlaku di lingkungan masyarakat serta hasil belajar di sekolah, secara berangsur-angsur akan dapat menentukan perilaku yang tepat menurut pandangan mereka.

Indikator dalam penelitian ini mengacu pada pendapat Santrock (2007) yang mengatakan bahwa teman sebaya mempunyai peran terpenting dalam perkembangan remaja yang terdiri atas tiga indikator, yaitu sebagai berikut: (a) Sebagai sumber informasi mengenai dunia di luar keluarga; (b) Sumber kognitif, dalam pemecahan masalah dan perolehan pengetahuan; (c) Sumber emosional, untuk mengungkapkan ekspresi dan identitas diri.

Dengan demikian tujuan penelitian ini antara lain: (a) Menganalisis pengaruh literasi ekonomi siswa, hasil belajar ekonomi, dan teman sebaya terhadap perilaku konsumsi siswa secara parsial; (b) Menganalisis pengaruh literasi ekonomi siswa, hasil belajar ekonomi, dan teman sebaya terhadap perilaku konsumsi siswa secara simultan.

\section{METODE PENELITIAN}

Pendekatan yang digunakan dalam penelitian ini adalah pendekatan kuantitatif dengan menggunakan analisis regresi berganda. Desain penelitian ini adalah kausal yang berguna untuk menganalisis hubungan antara variabel satu dengan variabel lainnya atau bagaimana suatu variabel mempengaruhi variabel lainnya (Umar, 2003). Sedangkan metode yang digunakan dengan menggunakan metode analisis diskriptif dan analisis regresi. Teknik analisis data yang digunakan adalah kuantitatif deskriptif dan regresi berganda. Analisis kuantitatif deskriptif digunakan untuk mengetahui mean dari masingmasing variabel penelitian. Sedangkan analisis regresi berganda digunakan untuk mengetahui besarnya hubungan antara variabel bebas dan terikat baik secara parsial maupun secara simultan.

Untuk analisis deskriptif tiap indikator dalam suatu variabel dengan menghitung mean pada masing-masing indikator. Untuk analisis regresi yaitu regresi linier berganda, dimana pada penelitian ini terdapat tiga variabel bebas/dependen terhadap satu variabel dengan rumus persamaannya sebagai berikut (Riduwan : 2012):

\section{$Y=a+b_{1} X_{1}+b_{2} X_{2}+b_{1} X_{1}+o 1$}

Variabel dalam penelitian ini adalah literasi ekonomi siswa $\left(\mathrm{X}_{1}\right)$, hasil belajar ekonomi $\left(\mathrm{X}_{2}\right)$, dan teman sebaya $\left(\mathrm{X}_{3}\right)$ sebagai variabel bebas, sedangkan perilaku konsumsi siswa (Y) sebagai variabel terikat. Populasi dalam penelitian ini adalah siswa kelas VIII SMP Negeri 28 Surabaya sebanyak 369 siswa dan siswa kelas VIII SMP Negeri 40 Surabaya sebanyak 330 siswa, sehingga jumlah populasi secara keseluruhan 699 siswa. Sedangkan 
sampel penelitian ditentukan dengan menggunakan rumus slovin, sebagai berukut (dalam Riduwan :2007):

$$
\mathrm{n}=\frac{\mathrm{N}}{\mathrm{N}\left(\mathrm{d}^{2}\right)+1}
$$

$$
\begin{aligned}
\text { Dimana }: \mathrm{n} & =\text { ukuran sampel } \\
\mathrm{N} & =\text { populasi } \\
\mathrm{D} & =\text { taraf nyata atau batas kesalahan }
\end{aligned}
$$

Dengan besarnya e $=5 \%$, sehingga diperoleh ukuran sampel sebesar 254 siswa. Besarnya distribusi sampel untuk masing-masing sekolah dan kelas dapat dihitung dengan menggunakan rumus William G. Cochran (dalam Prijana, 2005), yaitu :

$$
n_{k}=\frac{N_{k}}{N} \times \mathbf{n}
$$

Keterangan : $\mathrm{n}_{\mathrm{h}}=$ jumlah sampel strata

$$
\begin{aligned}
& \mathrm{n}=\text { jumlah sampel keseluruhan } \\
& \mathrm{N}_{\mathrm{h}}=\text { jumlah sub populasi atau strata } \\
& \mathrm{N}=\text { jumlah populasi }
\end{aligned}
$$

Dari hasil perhitungan maka dapat ditentukan jumlah masing-masing sampel yaitu SMP Negeri 28 Surabaya sebanyak 134 siswa dan SMP Negeri 40 Surabaya sebanyak 120 siswa. Adapun tehnik sampling yang digunakan dalam penelitian ini menggunakan teknik proportional random sampling.

Metode pengumpulan data yang digunakan dalam penelitian ini adalah angket (kuesioner) tertutup dan terbuka serta dokumentasi. Angket tertutup digunakan untuk mengungkap variabel literasi ekonomi siswa $\left(\mathrm{X}_{1}\right)$, teman sebaya, dan perilaku konsumsi siswa, angket terbuka digunakan untuk melengkapi data pada variabel literasi ekonomi, teman sebaya dan perilaku konsumsi, sedangkan metode dokumentasi digunakan untuk mengumpulkan data hasil belajar ekonomi siswa yang berupa daftar nilai ulangan harian IPS materi ekonomi kelas VIII semester genap tahun pelajaran 2014-2015.

\section{HASIL PENELITIAN DAN PEMBAHASAN}

Variabel literasi ekonomi terdiri dari 4 indikator yaitu mampu menjelaskan pendapatan individu, mampu menjelaskan penggunaan sumber daya yang terbatas, mampu menganalisis cost dan benefit dalam transaksi ekonomi, dan mampu menganalisis cost dan benefit dari pengambilan keputusan. Pada indikator mampu menjelaskan pendapatan individu memperoleh mean 3,404 dalam kategori cukup tinggi, pada indikator mampu menjelaskan penggunaan sumber daya yang terbatas memperoleh mean 3,658 dalam kategori tinggi, indikator mampu menganalisis cost dan benefit dalam transaksi ekonomi memperoleh mean 3,764, sedangkan pada indikator mampu menganalisis cost dan benefit dari pengambilan keputusan memperoleh mean 3,477 . Secara keseluruhan mean indikator dalam variabel literasi ekonomi nilai meannya 3,576 dalam kategori tinggi. Hal ini dapat disimpulkan bahwa siswa 
SMP Negeri di Surabaya Wilayah Barat memiliki tingkat literasi ekonomi yang baik.

Variabel hasil belajar ekonomi indikatornya menggunakan dokumentasi hasil nilai ulangan harian IPS sub-sub tema ekonomi semester genap tahun pelajaran 2014-2015. Dengan KKM 78, dari perhitungan data nilai ulangan harian siswa diperoleh rata-rata 81,87 dalam kategori cukup baik. Hal ini menunujukkan hasil belajar siswa SMP Negeri di Surabaya Wilayah Barat cukup baik.

Variabel teman sebaya terdiri dari tiga indikator yaitu sebagai sumber informasi tentang dunia diluar keluarga, sebagai sumber kognitif untuk pemecahan masalah dan untuk perolehan pengetahuan, dan sebagai sumber emosional untuk mengungkapkan ekspresi dan identitas diri. Indikator yang paling tinggi adalah sebagai sumber kognitif untuk pemecahan masalah dan untuk perolehan pengetahuan dengan mean 3,820 dalam kategori tinggi, sedangkan indikator sebagai sumber informasi tentang dunia di luar keluarga memperoleh mean 3,782, dan yang paling rendah adalah indikator sebagai sumber emosional untuk mengungkapkan ekspresi dan identitas diri memperoleh mean paling rendah yaitu 3,357 dalam kategori cukup tinggi. Secara keseluruhan dari ketiga indikator teman sebaya memperoleh mean sebesar 3,653 dalam kategori tinggi, maka dapat disimpulkan bahwa teman sebaya memiliki peran yang baik bagi siswa SMP Negeri di Surabaya Wilayah Barat.

Variabel perilaku konsumsi terdiri atas tiga indikator yaitu pemenuhan kebutuhan sesuai intensitas, motif melakukan konsumsi, dan penerapan prinsip ekonomi dalam konsumsi. Pada indikator pemenuhan kebutuhan sesuai ientensitas memiliki mean paling tinggi yaitu 3,773 dalam kategori tinggi. Hal ini dapat dilihat dari masing-masing subindikator kebutuhan primer, kebutuhan sekunder, kebutuhan tersier mencapai kategori tinggi. Pada indikator motif melakukan konsumsi yang meliputi tiga sub indikator memperoleh mean paling rendah yaitu 3,542 namun masih dalam kategori tinggi. Indikator penerapan prinsip ekonomi dalam konsumsi memperoleh mean 3,704 dalam kategori tinggi. Secara keseluruhan dari ketiga indikator memiliki mean 3,673 dalam kategori tinggi, hal ini berarti siswa SMP Negeri di Surabaya Wilayah Barat memiliki perilaku konsumsi yang baik.

Dari hasil angket terbuka menunjukkan bahwa siswa SMP Negeri di Surabaya Wilayah Barat sebagian besar sangat aktif dalam organisasi/klub yaitu sebanyak 219 siswa (86,22 \%). Data jumlah uang saku siswa per minggu rata-rata sebesar Rp 103.031,50 dalam kategori cukup tinggi. Jumlah siswa yang menabung sebanyak 179 siswa dalam kategori tinggi, sebagian siswa ada yang menabung per minggu dengan rata-rata sebesar Rp 12.142,86, sedangkan yang menabung per bulan rata-rata sebesar Rp 74.303,03. Siswa SMP Negeri di Surabaya Wilayah Barat juga banyak yang suka jalan-jalan ke mall/pertokoan yaitu sebanyak 133 orang $(52,4 \%)$ dalam kategori cukup tinggi. Sedangkan siswa yang suka makan/minum di kafe sebanyak 115 orang $(45,28 \%)$.

Berdasarkan hasil analisis yang dilakukan untuk variabel bebas literasi ekonomi siswa, hasil belajar ekonomi, dan teman sebaya dengan variabel 
terikatnya (dependent variable) perilaku konsumsi diperoleh hasil output sebagai berikut:

Coefficients

\begin{tabular}{|rl|r|r|r|r|r|}
\hline \multirow{2}{*}{ Model } & \multicolumn{2}{|c|}{$\begin{array}{c}\text { Unstandardized } \\
\text { Coefficients }\end{array}$} & $\begin{array}{c}\text { Standardized } \\
\text { Coefficients }\end{array}$ & & \\
\cline { 2 - 5 } & \multicolumn{1}{|c|}{$\mathrm{B}$} & Std. Error & \multicolumn{1}{c|}{ Beta } & \multicolumn{1}{c|}{$\mathrm{t}$} & \multicolumn{1}{c|}{ Sig. } \\
\hline 1 & (Constant) & -.322 & .130 & & -2.481 & .014 \\
& Literasi Ekonomi (X1 & .243 & .045 & .231 & 5.461 & .000 \\
& Hasil Belajar (X2) & .018 & .002 & .362 & 11.484 & .000 \\
& Teman Sebaya (X3) & .479 & .041 & .485 & 11.608 & .000 \\
\hline
\end{tabular}

a. Dependent Variable: Perilaku Konsumsi (Y)

Dari hasil tersebut dapat diperoleh analisis regresi linear berganda, sebagai berikut:

$$
\mathrm{Y}=-0,322+0,243 \mathrm{X} 1+0,018 \mathrm{X} 2+0,479 \mathrm{X} 3+\mathrm{e} .
$$

Dari persamaan tersebut dapat dijelaskan sebagai berikut:

1. Konstanta yang dihasilkan sebesar $-0,322$ mempunyai makna bahwa besarnya perilaku konsumsi siswa turun sebesar 0,322 jika variabel literasi ekonomi $\left(\mathrm{X}_{1}\right)$, hasil belajar ekonomi $\left(\mathrm{X}_{2}\right)$, dan teman sebaya $\left(\mathrm{X}_{3}\right)$ adalah konstan.

2. Koefisien regresi pada variabel literasi ekonomi adalah positif sebesar 0,243. Artinya jika literasi ekonomi naik satu satuan, maka perilaku konsumsi siswa akan naik sebesar 0,243 dengan asumsi variabel hasil belajar ekonomi dan teman sebaya adalah konstan.

3. Koefisien regresi pada variabel hasil belajar ekonomi adalah positif yaitu sebesar 0,018. Artinya jika hasil belajar ekonomi naik satu satuan, maka perilaku konsumsi siswa akan naik sebesar 0,018 dengan asumsi variabel literasi ekonomi dan teman sebaya adalah konstan.

4. Koefisien regresi pada variabel teman sebaya adalah positif yaitu sebesar 0,479 . Artinya jika teman sebaya naik satu satuan, maka perilaku konsumsi siswa akan naik sebesar 0,479 dengan asumsi variabel literasi ekonomi dan hasil belajar ekonomi adalah konstan.

Untuk uji hipotesis secara parsial (uji t) hasil analisis menunjukkan hasil untuk variabel literasi ekonomi, dapat dilihat bahwa nilai Thitung untuk variabel literasi ekonomi yaitu 5,461, untuk $T_{\text {tabel }}$ dengan taraf signifikan 0,05 diperoleh 2,10982, sedangkan nilai signifikansinya 0,000 lebih kecil dari 0,05. Karena $\mathrm{T}_{\text {hitung }}>\mathrm{T}_{\text {tabel }}$ maka Ho ditolak dan Ha diterima. Dengan demikian hipotesis 1 diterima dan hasilnya ada pengaruh positif antara variabel literasi ekonomi $\left(\mathrm{X}_{1}\right)$ terhadap perilaku konsumsi (Y).

Untuk variabel hasil belajar ekonomi dapat dilihat bahwa nilai $\mathrm{T}_{\text {hitung }}$ untuk variabel hasil belajar ekonomi yaitu 11,484, untuk $T_{\text {tabel }}$ dengan taraf signifikan 0,05 diperoleh 2,10982, sedangkan nilai signifikansinya 0,000 lebih kecil dari 0,05 . Karena $T_{\text {hitung }}>T_{\text {tabel }}$ maka Ho ditolak dan Ha diterima. Dengan demikian hipotesis 2 diterima dan hasilnya ada pengaruh positif antara variabel hasil belajar ekonomi terhadap perilaku konsumsi (Y). 
Untuk variabel teman sebaya dapat dilihat bahwa nilai $\mathrm{T}_{\text {hitung }}$ untuk variabel teman sebaya yaitu 11,608 , untuk $T_{\text {tabel }}$ dengan taraf signifikan 0,05 diperoleh 2,10982, sedangkan nilai signifikansinya 0,000 lebih kecil dari 0,05. Karena $\mathrm{T}_{\text {hitung }}>\mathrm{T}_{\text {tabel }}$ maka Ho ditolak dan Ha diterima. Dengan demikian hipotesis 2 diterima dan hasilnya ada pengaruh positif antara variabel teman sebaya terhadap perilaku konsumsi (Y).

Uji hipotesis secara simultan menunjukkan nilai F hitung yaitu 344,850, sedangkan nilai $\mathrm{F}_{\text {tabel }}$ dapat diperoleh dengan menggunakan tabel $\mathrm{F}$ dengan tarap siginifikan 0,05 , sehingga diperoleh nilai $F$ tabel yaitu 2,64. Karena $F_{\text {hitung }}$ $344,8850>$ F tabel 2,64 maka model signifikan. Berdasarkan nilai signifikan, terlihat pada kolom sig yaitu 0,000 jadi signifikasi kurang dari 0,05, maka Ho ditolak pada derajat kepercayaan 5\%, dengan kata lain Ha diterima, sehingga hipotesis 4 diterima yang menyatakan bahwa ada pengaruh antara variabel literasi ekonomi siswa $\left(\mathrm{X}_{1}\right)$, hasil belajar ekonomi $\left(\mathrm{X}_{2}\right)$, dan teman sebaya $\left(\mathrm{X}_{3}\right)$ terhadap perilaku konsumsi siswa (Y) SMP Negeri di Surabaya Wilayah Barat.

Sedangkan nilai koefisien determinasi (R-Square) yang dihasilkan dalam penelitian ini dapat dilihat pada tabel berikut:

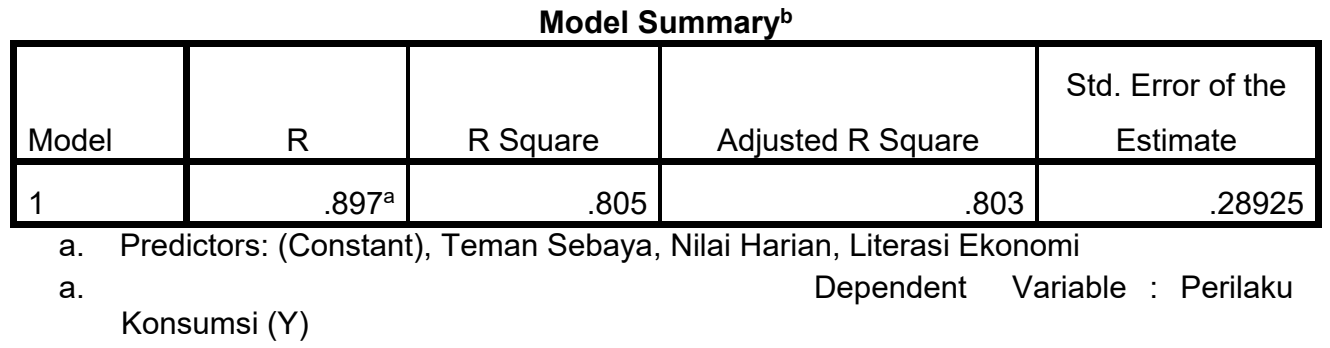

Berdasarkan tabel di atas, menunjukkan bahwa koefisien determinasi (Adjusted R-square) dalam penelitian ini sebesar 0.803. hal ini berarti literasi ekonomi siswa, hasil belajar ekonomi, dan teman sebaya berpengaruh terhadap perilaku konsumsi siswa sebesar 80,3\%, sedangkan sisanya 19,7\% dipengaruhi oleh faktor lain yang tidak dibahas dalam penelitian ini.

Untuk pembahasan pengaruh masing-masing variabel bebas terhadap variabel terikat maupun pengaruh variabel bebas secara bersama-sama terhadap variabel terikat adalah sebagai berikut:

\section{Pengaruh Literasi Ekonomi Siswa Terhadap Perilaku Konsumsi Siswa}

Berdasarkan hasil analisis data penelitian menunjukkan bahwa literasi ekonomi siswa mempunyai pengaruh yang signifikan terhadap perilaku konsumsi siswa. Hasil tersebut mempunyai makna bahwa setiap perubahan variabel literasi ekonomi akan berpengaruh positif pada perilaku konsumsi siswa. Semakin tinggi literasi ekonomi siswa memberikan makna tingkat pemahaman siswa terhadap konsep-konsep dasar ekonomi yang semakin baik, maka akan dapat memberikan pengaruh terhadap perilaku konsumsi yang positif.

Hasil temuan ini menunjukkan bahwa literasi ekonomi siswa berpengaruh terhadap perlaku konsumsi siswa seperti hasil penelitian terdahulu yang dilakukan oleh Yanti (2014) yang menemukan bahwa secara parsial 
penguasaan konsep ekonomi berpengaruh terhadap pola perilaku konsumsi siswa. Hasil penelitian ini juga didukung oleh hasil penelitian terdahulu Wahyuni (2011) dan Daroin (2010). Hasil penelitian ini sesuai dengan teori Salemi (2005) yang menjelaskan bahwa siswa mencapai literasi ekonomi jika mereka dapat menerapkan konsep dasar ekonomi pada tahun-tahun kemudian, dalam situasi yang relevan dengan kehidupan mereka dan berbeda dari yang dihadapi di kelas misalnya dalam perilaku konsumsinya sehari-hari. Hal ini juga diperkuat oleh Bayhanvd dalam Nuray Mercan, dkk (2014), bahwa dengan memiliki literasi ekonomi membuat kita lebih mudah dalam memahami dunia dimana kita hidup, menyebabkan orang untuk lebih rasional dan partisipatif, dan memungkinkan kita untuk memahami batas-batas dan potensi kebijakan ekonomi.

Literasi ekonomi siswa pada penelitian ini terdapat 4 indikator, yaitu mampu menjelaskan pendapatan individu; mampu menjelaskan penggunaan sumber daya yang terbatas; mampu menganalisis cost dan benefit dari transaksi ekonomi; mampu menganalisis cost dan benefit dari pengambilan keputusan. Berdasarkan tanggapan responden diketahui bahwa pada indikator mampu menganalisis cost dan benefit dalam transaksi ekonomi memiliki nilai rata-rata paling tinggi. Menganalisis cost dan benefit merupakan kemampuan bagaimana mempertimbangkan antara biaya dan manfaat dalam aktivitas ekonomi. Hal ini sesuai dengan pendapat Haryono (2008), bahwa literasi ekonomi adalah kemampuan untuk mengidentifikasi masalah-masalah ekonomi, penyusunan alternatif pemecahan dengan mempertimbangkan benefit dan cost.

Pada indikator mampu menjelaskan penggunaan sumber daya yang terbatas, misalnya dalam penggunaan uang saku dan produk rumah tangga (air, lampu, listrik) juga menunjukkan rerata dengan kategori tinggi yang artinya siswa dapat memanfaatkan dengan baik penggunaan sumber daya yang terbatas dalam perilaku konsumsinya. Hal ini sesuai dengan pendapat Caplan (dalam Kustiandi, 2011) bahwa literasi ekonomi merupakan pengetahuan ekonomi yang diperlukan karena setiap manusia tidak terlepas dari masalah ekonomi yang berkaitan dengan bagaimana manusia dapat memanfaatkan keterbatasan sumber daya yang dimiliki. Peter Sina (2012) juga sependapat, bahwa literasi ekonomi merupakan pemahaman seseorang yang terkristalkan dalam membuat pilihan yang cerdas terkait alokasi sumber daya.

Hasil temuan lainnya dari indikator mampu menjelaskan penggunaan sumber daya yang terbatas dapat diketahui juga bahwa masih tingginya minat siswa untuk menabung. Berdasarkan hasil data angket terbuka diketahui jumlah siswa yang menabung dalam kategori tinggi. Hal ini sesuai dengan hasil penelitian Yunus, dkk (2010) bahwa literasi ekonomi berhubungan positif dengan niat menabung. Bahkan menurut pendapat Mathews dalam Sina (2012) bahwa manfaat mempelajari literasi ekonomi yakni antara lain menjadi penabung.

Rerata yang tinggi juga terdapat pada indikator menganalisis cost dan benefit dalam pengambilan keputusan. Hasil penelitian ini sesuai dengan pernyataan Wulandari (2011), bahwa literasi ekonomi adalah keterampilan hidup (life skill) yang harus dimiliki oleh siapa saja untuk membuat keputusan ekonomi yang tepat.Manusia ekonomi yang rasional akan senantiasa mengutamakan manfaat apa yang diperoleh dari tindakan ekonominya, 
misalnya dalam membeli barang sebagian besar siswa memilih pertimbangan harga yang murah dengan kualitas yang baik. Apabila barang yang dibutuhkan harganya naik, mereka akan memilih barang lain dengan kualitas yang sama dengan harga yang lebih murah.

Sedangkan hasil temuan pada indikator mampu menjelaskan pendapatan individu menunjukkan rerata kategori cukup tinggi yang artinya pemahaman siswa cukup baik dalam menggali sumber-sumber pendapatan individu. Seperti yang diungkapkan oleh Mathews (1999) bahwa literasi ekonomi sebagai kemampuan individu untuk mengenali dan menggunakan konsep-konsep ekonomi dan cara berpikir ekonomi untuk memperbaiki dan mendapatkan kesejahteraan misalnya bagaimana upaya siswa untuk dapat menambah uang sakunya. Untuk itu, literasi ekonomi ini sangat penting bagi siswa terutama dalam melatih kemampuan siswa untuk mengatasi permasalahan ekonomi yang dihadapi siswa sehari-hari.

Berdasarkan temuan hasil penelitian variabel literasi ekonomi siswa pada masing-masing indikator, maka dapat diurutkan jawaban tertinggi sampai terendah, yaitu urutan pertama yaitu mampumenganalisis cost dan benefit dalam transaksi ekonomi, urutan kedua mampu menjelaskan penggunaan sumber daya yang terbatas, urutan ketiga mampu menganalisis cost dan benefit dalam pengambilan keputusan, sedangkan urutan yang paling rendah adalahmampu menjelaskan pendapatan individu. Sehingga dapat dipahami bahwa indikator menjelaskan pendapatan individu dapat lebih ditingkatkan dengan cara guru melatih kreativitas siswa dalam upaya menanamkan jiwa wirausaha untuk dapat menggali sumber-sumber pendapatan siswa.

Berdasarkan uraian tersebut dapat disimpulkan bahwa siswa kelas VIII SMP Negeri di Surabaya Wilayah Barat secara umum memiliki literasi ekonomi yang baik. Dengan demikian maka guru IPS dalam memberikan materi pelajaran ekonomi kepada siswa lebih menekankan pada aspek keterampilan (psikomotor) agar dapat meningkatkan kemampuan siswa dalam menggali sumber pendapatan dan literasi ekonomi siswa tetap baik.

\section{Pengaruh Hasil Belajar Ekonomi Siswa terhadap Perilaku Konsumsi Siswa}

Berdasarkan hasil analisis data penelitian menunjukkan bahwa hasil belajar ekonomi mempunyai pengaruh yang signifikan terhadap perilaku konsumsi siswa. Hasil tersebut mempunyai makna semakin tinggi hasil belajar ekonomi siswa maka akan dapat memberikan pengaruh terhadap perilaku konsumsi yang positif.

Hasil temuan ini menunjukkan bahwa hasil belajar ekonomi siswa berpengaruh terhadap perlaku konsumsi siswa seperti hasil penelitian terdahulu yang dilakukan oleh Purwati (2011), ditemukan bahwa prestasi belajar ekonomi siswa berpengaruh secara positif dan signifikan terhadap perilaku konsumsi siswa. Hal ini berarti siswa yang hasil belajar ekonominya baik, maka perilaku konsumsinya juga baik. Sejalan dengan hasil penelitian Purwati, hasil penelitian Hadija (2013) juga ditemukan bahwa prestasi belajar ekonomi secara parsial berpengaruh terhadap perilaku konsumsi siswa.

Menurut Mulyasa (2008), hasil belajar merupakan prestasibelajar siswa secara keseluruhan yang menjadi indikator kompetensi dan derajat perilaku 
yang bersangkutan. Kompetensi yang harus dikuasai siswa perlu dinyatakan sedemikian rupa agar dapat dinilai sebagai wujud hasil belajar siswa yang mengacu pada pengalaman langsung.Dalam proses belajar, seorang siswa dibentuk dengan sedemikian rupa agar siswa tersebut mampu dan cakap untuk mengatasi masalah-masalah dalam menjalani kehidupannya sesuai dengan tuntutan disiplin ilmu yang sudah dipelajarinya dan menjadi dasar bagi seorang siswa dalam bertindak dan berperilaku ekonomi terutama dalam melakukan tindakan konsumsi.

Seperti yang diungkapkan Zamroni dalam Prasastianta (2011) bahwa secara umum tindakan manusia senantiasa telah direncanakan sebelumnya yang dilakukan secara sadar melalui pemikiran yang matang dalam konteks ekonomi, manusia senantiasa mendasari tindakannya untuk mencapai efisiensi dan efektifitas ekonomi. Kemampuan dalam merencanakan melalui pemikiran yang matang dalam konteks ekonomi dapat dicapai siswa sebagai hasil dari pengalaman belajar dalam proses pembelajaran ekonomi. Seperti yang dinyatakan Hadija (2013) bahwa pengalaman belajar merupakan salah satu faktor intern (psikologis) yang mempengaruhi perilaku kosumsi.

Menurut Dimyati dan Mudjiono (2006), hasil belajar adalah hasil yang dicapai dalam bentuk angka-angka atau skor setelah diberikan tes hasil belajar pada setiap akhir pembelajaran. Sesuai dengan Peraturan pemerintah RI No. 19/2005 tentang standar nasional pendidikan bagian kedua tentang penilaian hasil belajar oleh pendidik pasal 64 berbunyi sebagai berikut : ayat (1) penilaian hasil belajar oleh pendidik sebagaimana dimaksud dalam pasal 63 ayat 910 butir (a) dilakukan secara berkesinambungan untuk memantau proses, kemajuan, dan perbaikan hasil dalam bentuk ulangan harian, ulangan tengah semester, ulangan akhir semester dan ulangan kenaikan kelas.

Dengan demikian indikator hasil belajar ekonomi yang digunakan pada penelitian ini adalah menggunakan instrumen berupa dokumentasi tentang hasil nilai ulangan harian IPS materi ekonomikelas VIII semester genap dengan tema III : Fungsi dan peran sumber daya alam dalam pembangunan nasional, sub-sub tema C.1 Fungsi dan peran sumber daya alam dalam pembangunan ekonomi. Dari hasil analisa data diketahui hasil nilai ulangan harian IPS materi ekonomi siswa SMP Negeri di Surabaya Wilayah Barat menunjukkan nilai rata-rata yang cukup baik.

Sedangkan hasil temuan perilaku konsumsi siswa menunjukkan kategori tinggi, hal ini dapat dilihat pada indikator pemenuhan kebutuhan sesuai intensitas, motif melakukan konsumsi, dan penerapan prinsip ekonomi, masing-masing memperoleh nilai rerata yang tinggi. Maka dapat disimpulkan bahwa perilaku konsumsi siswa SMP Negeri di Surabaya Wilayah Barat memiliki perilaku konsumsi yang baik.

Berdasarkan uraian tersebut dapat disimpulkan bahwa hasil belajar ekonomi siswa SMP Negeri di Surabaya Wilayah Barat berpengaruh terhadap perilaku konsumsi siswa. Dengan demikian guru perlu meningkatkan metode mengajarnya dalam pemberian materi ekonomi yang lebih baik lagi agar hasil belajar ekonomi siswa meningkat dan dapat diaplikasikan siswa dalam perilaku ekonominya sehari-hari khususnya dalam perilaku konsumsi yang lebih baik lagi. 


\section{Pengaruh Teman Sebaya terhadap Perilaku Konsumsi Siswa}

Berdasarkan hasil analisis data penelitian menunjukkan bahwa teman sebaya mempunyai pengaruh yang signifikan terhadap perilaku konsumsi siswa. Hasil tersebut mempunyai makna semakin tinggi peran teman sebaya maka akan dapat memberikan pengaruh terhadap perilaku konsumsi yang positif.

Hasil temuan ini menunjukkan bahwa teman sebaya berpengaruh terhadap perlaku konsumsi siswa. Hal ini sesuai dengan hasil penelitian terdahulu yang dilakukan oleh Hadija (2013), ditemukan bahwa teman sebaya berpengaruh secara positif dan signifikan terhadap perilaku konsumsi siswa. Hasil penelitian ini juga didukung oleh hasil penelitian terdahulu Harari\& Hornik (2010) bahwa teman sebaya berpengaruh terhadap keterlibatan produk konsumen remaja.

Hasil penelitian ini sesuai dengan pendapat Schiffman dan Kanuk (2008), bahwa dari segi pengaruh sesudah keluarga, teman-teman paling mungkin mempengaruhi keputusan pembelian mereka. Pendapat yang sama juga dari Peter dan Olson (2010), bahwa selain ayah dan ibu, keputusan pembelian pada anak-anak dan orang dewasa, keduanya sangat dipengaruhi oleh teman sebaya.

Laursen (2005) menandaskan bahwa teman sebaya merupakan faktor yang sangat berpengaruh terhadap kehidupan pada masa-masa remaja. Mereka sering berkumpul menghabiskan waktu luang mereka untuk berbagi informasi dan pengalaman baik dengan teman sekolah maupun teman dalam klub, atau organisasi. Teman sebaya menjadi rujukan dalam pergaulan para remaja. Merujuk pada pendapat Schiffman \& Kanuk (2008), bahwa kelompok rujukan adalah setiap orang atau kelompok yang dianggap sebagai dasar perbandingan atau rujukan bagi seseorang dalam membentuk nilai-nilai dan sikap umum atau khusus, atau pedoman khusus bagi perilaku.

Teman sebaya dalam penelitian ini terdapat tiga indikator yaitu sumber informasi tentang dunia di luar keluarga, sumber kognitif untuk pemecahan masalah dan untuk perolehan pengetahuan, dan sumber emosional untuk mengungkapkan ekspresi dan identitas diri. Hasil temuan dari tanggapan responden pada indikator sumber kognitif untuk pemecahan masalah dan untuk perolehan pengetahuan menunjukkan rerata yang paling tinggi. Hal ini sesuai dengan pendapat Santrock (2007), bahwa teman sebaya mempunyai peran sebagai sumber kognitif untuk pemecahan masalah dan untuk perolehan pengetahuan.

Melalui pergaulan dengan teman sebaya ternyata dapat memberikan pengaruh antara lain para siswa seringkali meminta pertimbangan temannya ketika mereka menghadapi masalah, mereka juga sering berdiskusi dengan teman kelompoknya sehingga dapat memunculkan ide-ide baru dan pengetahuan baru. Sejalan dengan pendapat Santrock, Ormrod (2008) berpendapat bahwa teman sebaya memiliki peran sebagai medan pembelajaran dan pelatihan berbagai keterampilan sosial bagi para remaja.

Dalam pergaulan dengan teman sebayanya, dengan melihat pengalaman teman-temannya, mereka dapat membedakan hal positif dan negatif dari perilaku teman-temannya. Adakalanya para siswa memiliki kecenderungan meniru atau mengikuti baik secara sukarela maupun karena terpaksa kebiasaan teman-temannya yang terkadang beresiko, misalnya tindakan merokok. minum 
minuman keras yang biasanya dilakukan remaja laki-laki. Menurut hasil penelitian Gardner \& Steinberg (2005), bahwa pengambilan keputusan beresiko dari teman sebaya pengaruhnya lebih kuat di kalangan remaja, yaitu masih menurut Gardner \& Steinberg usia remaja adalah 13-16 tahun. Hasil penelitian Clark \& Loheac (2005), dan Geckova, dkk (2005) menemukan bahwa teman sebaya berpengaruh signifikan terhadap perilaku merokok, minum, mabuk-mabukan di kalangan remaja laki-laki.Kebiasaan-kebiasaan tersebut mereka lakukan agar mereka dapat diterima dan diakui dalam kelompok temannya, seperti yang dikemukakan oleh Hoyer dan MacInnis (2008) bahwa konformitas adalah kecenderungan bagi seorang individu untuk berperilaku sebagaimana kelompoknya berperilaku.

Pada indikator sumber informasi tentang dunia di luar keluarga juga menunjukkan rerata yang tinggi. Hal ini sesuai dengan pendapat Santrock (2007) bahwa salah satu fungsi teman sebaya sebagai sumber informasi tentang dunia di luar keluarga. Melalui pergaulan teman, mereka dapat mengetahui barang-barang yang sedang tren yang tidak mereka dapatkan dalam lingkungan keluarga.

Pada indikator yang ketiga yaitu sumber emosional untuk mengungkapkan ekspresi dan identitas diri menunjukan rerata cukup tinggi.Untuk mengungkapkan ekspresi mereka, para siswa sering berkumpul dengan teman-temannya dari pada dengan keluarga, misalnya mereka suka jalan-jalan di mall atau makan-minum di kafe. Dari analisis data dapat diketahui siswa kelas VIII SMP Negeri di Surabaya Wilayah Barat yang suka jalan-jalan ke mall/pertokoan dan suka makan/minum di kafe tergolong cukup tinggi. Hal ini dikarenakan adanya kebiasaan siswa mentraktir teman-temannya ketika mereka sedang bergembira/ mendapatkan rizki yang juga memiliki kategori cukup tinggi.

Mereka membutuhkan teman sebayanya untuk dapat meluapkan emosi sebagai perwujudan ekspresi kebahagiaan ataupun menunjukkan identitas diri mereka. Kondisi ini sesuai dengan pendapat Santrock (2007) bahwa teman sebaya memiliki peran sebagai sumber emosional untuk mengungkapkan ekspresi dan identitas diri.

Berdasarkan temuan hasil penelitian variabel teman sebaya pada masingmasing indikator, maka dapat diurutkan jawaban tertinggi sampai terendah, yaitu urutan pertama pada indikator sumber kognitif untuk pemecahan masalah dan untuk perolehan pengetahuan, urutan kedua sumber informasi tentang dunia di luar keluarga, sedangkan urutan yang paling rendah adalah sumber emosional untuk mengungkapkan ekspresi dan identitas diri. Sehingga dapat dipahami bahwa pada indikator sumber emosional untuk mengungkapkan ekspresi dan identitas diri lebih ditingkatkan dengan cara guru memberikan pemahaman kepada siswa untuk dapat mengekspresikan diri pada kegiatan yang positif agar peran teman sebaya dapat bermanfaat dalam bentuk pengendalian diri siswa dalam menghindari perilaku konsumtif.

Berdasarkan uraian tersebut dapat disimpulkan bahwa peran teman sebaya memiliki peran yang tinggi dalam pergaulan siswa kelas VIII SMP Negeri di Surabaya Wilayah Barat. Dengan demikian maka peran guru dan orang tua sangat penting untuk dapat meningkatkan pengawasan dalam 
pergaulan para siswa agar teman sebaya dapat memberikan pengaruh yang baik bagi perkembangan pribadi siswa.

\section{Pengaruh Literasi Ekonomi Siswa, Hasil Belajar Ekonomi, dan Teman Sebaya terhadap Perilaku Konsumsi Siswa}

Berdasarkan hasil analisis regresi linier berganda diperoleh hasil bahwa secara statistik mengenai pengaruh literasi ekonomi siswa, hasil belajar ekonomi, dan teman sebaya terhadap perilaku konsumsi siswa SMP Negeri di Surabaya Wilayah Barat menunjukkan bahwa secara simultan (bersama-sama) variabel bebas literasi ekonomi siswa, hasil belajar ekonomi, dan teman sebaya berpengaruh signifikan dan positif terhadap perilaku konsumsi siswa SMP Negeri di Surabaya Wilayah Barat. Besarnya pengaruh literasi ekonomi siswa, hasil belajar ekonomi, dan teman sebaya secara simultan terhadap perilaku konsumsi siswa SMP Negeri di Surabaya Wilayah Barat dapat dilihat dari koefisien determinasi (R-square). Nilai (R-square) yang dihasilkan menunjukkan perilaku konsumsi siswa dipengaruhi oleh literasi ekonomi siswa, hasil belajar ekonomi, dan teman sebaya.

Berdasarkan temuan hasil penelitian ini menunjukkan bahwa literasi ekonomi siswa, hasil belajar ekonomi, dan teman sebaya berpengaruh signifikan dan positif terhadap perilaku konsumsi siswa seperti hasil penelitian terdahulu yang meneliti variabel teman sebaya dan hasil belajar dilakukan oleh Hadija (2013), yang mengatakan bahwa teman sebaya dan prestasi belajar ekonomi berpengaruh signifikan pada perilaku konsumsi siswa. Peneliti terdahulu Purwati (2011) mengatakan bahwa prestasi belajar ekonomi berpengaruh signifikan pada perilaku konsumsi siswa.

Demikian juga hasil penelitian Wulandari (2011), mengatakan bahwa penguasaan konsep dasar ekonomi (literasi ekonomi) berpengaruh signifikan terhadap perilaku konsumsi siswa, begitu juga hasil penelitian Wahyuni (2011), penguasaan konsep ekonomi berpengaruh signifikan terhadap perilaku konsumsi mahasiswa.

Berdasarkan uraian tersebut dapat disimpulkan bahwa siswa kelas VIII SMP Negeri di Surabaya Wilayah Barat secara umum literasi ekonomi siswa, hasil belajar ekonomi, dan teman sebaya berpengaruh signifikan dan positif terhadap perilaku konsumsi siswa. Dengan demikian maka dapat dipahami literasi ekonomi siswa yang baik, didukung hasil belajar ekonomi yang cukup baik, dan peran teman sebaya yang tinggi berpengaruh signifikan dan positif terhadap perilaku konsumsi siswa yang baik.

\section{SIMPULAN}

Terdapat pengaruh literasi ekonomi siswa terhadap perilaku konsumsi siswa SMP Negeri di Surabaya Wilayah Barat. Hal ini berarti literasi ekonomi siswa secara parsial berpengaruh signifikan dan positif terhadap perilaku konsumsi siswa. Hasil temuan pada penelitian ini lebih dominan didukung oleh dua indikator penggunaan sumber daya yang terbatas dan menganalisis cost dan benefit dalam transaksi ekonomi.Hal ini dapat ditunjukkan dari temuan bahwa sebagian besar siswa dapat memanfaatkan dengan baik penggunaan sumber daya yang terbatas yang berupa uang saku dan penggunaan produk 
rumah tangga serta masih tingginya minat siswa untuk menabung. Selain itu juga sebagian besar siswa dapat mempertimbangkan dengan baik antara cost dan benefit dalam melakukan pembelian barang kebutuhan.

Terdapat pengaruh hasil belajar ekonomi terhadap perilaku konsumsi siswa SMP Negeri di Surabaya Wilayah Barat. Hal ini berarti hasil belajar ekonomi secara parsial berpengaruh signifikan dan positif terhadap perilaku konsumsi siswa. Hasil temuan pada penelitian ini didukung oleh hasil ulangan harian yang dicapai siswa pada mata pelajaran IPS materi ekonomi kelas VIII semester genap tahun pelajaran 2014-2015. Hal ini dapat ditunjukkan dari temuan bahwa sebagian besar siswa memperoleh hasil ulangan harian mata pelajaran IPS materi ekonomi cukup baik.

Terdapat pengaruh teman sebaya terhadap perilaku konsumsi siswa SMP Negeri di Surabaya Wilayah Barat. Hal ini berarti teman sebaya secara parsial berpengaruh signifikan dan positif terhadap perilaku konsumsi siswa. Hasil temuan pada penelitian ini lebih dominan didukung dua indikator sumber informasi tentang dunia di luar keluarga dan sumber kognitif untuk pemecahan masalah dan untuk perolehan pengetahuan. Hal ini dapat ditunjukkan dari temuan bahwa teman sebaya memiliki peran yang tinggi sebagai sumber informasi atau rujukan utama selain keluarga oleh sebagian besar siswa. Selain itu juga teman sebaya memiliki peran tinggi sebagai sumber pengetahuan yang bermanfaat dalam memecahkan masalah yang dihadapi siswa.

Terdapat pengaruhliterasi ekonomi siswa, hasil belajar ekonomi, dan teman sebaya terhadap perilaku konsumsi siswa kelas VIII SMP Negeri di Surabaya Wilayah Barat. Hal ini berarti literasi ekonomi siswa, hasil belajar ekonomi, dan teman sebaya secara simultan berpengaruh signifikan dan positif terhadap perilaku konsumsi siswa. Hal ini berarti semakin tinggi literasi ekonomi siswa, semakin hasil belajar ekonomi, dan peran teman sebaya, maka semakin baik pengaruhnya terhadap perilaku konsumsi siswa kelas VIII SMP Negeri di Surabaya Wilayah Barat.

\section{DAFTAR RUJUKAN}

Ahmadi, Abu. (2007). Psikologi Sosial. Jakarta : Rineka Cipta

Arikunto, Suharsimi. (2000). Dasar-dasar Evaluasi Pendidikan. Jakarta : Bumi Aksara

Azhari, Akyas. 2004. Psikologi Umum dan Perkembangan. Bandung: Teraju.

Arnold, Mark J. dan Reynolds, Kristy. E. 2003. "Hedonic Shopping Motivation”. Journal of Retailing, Vol. 79 No.2, pp. 77-95.

Budiwati, Neti. 2014. Analisis Literasi Ekonomi dan Perilaku Konsumen (Survey pada Guru SMA di Kota Bandung). (Disertasi). Bandung : Universitas Pendidikan Indonesia.

Cauffman, E., \& Steinberg, L. 2000. Researching adolescents' judgment and culpability. In T. Grisso \& R. G. Schwartz (Eds.), Youth on trial: A developmental perspective on juvenile justice (pp. 325-343). Chicago: The University of Chicago. 
Chaplin, J. P. 2001. Kamus Lengkap Psikologi. Penerjemah: Dr. Kartini Kartono. Jakarta: PT. Raja Grafindo Persada

Clark, A. E. \& Loheac, Y. 2005. "It Wasn't Me, It was Them!" Social Influence in Risky Behavior by Adolescents. IZA Discussion Paper No. 1573, April 2005. Bonn, Germany : P.O. Box 7240

Damsar. 2009. Pengantar Sosiologi Ekonomi. Jakarta : Kencana Prenada Media

Damsar. 2011. Pengantar Sosiologi Ekonomi. Jakarta: Kencana Prenada Media.

Daroin, Ana Dhaoud. 2010. Pengaruh Kualitas Pembelajaran Ekonomi, Pengetahuan Dasar Ekonomi (Economic Literacy) dan Status Sosial Ekonomi Orang Tua terhadap Efisiensi dalam Berkonsumsi Siswa Kelas XI dan XII Ilmu Sosial SMAN 1 Malang. (Tesis). Malang: UM.

Departemen Pendidikan Nasional. 2001. Kurikulum Pendidikan SMP. http://nanunalmufarah.blogspot.com/2012/10/karakteristik-bidang-studiekonomi-unla.html diakses 21 nop 2014, pk. 23.10 wib

Dimyati dan Mudjiono. 2006. Belajar dan Pembelajaran. Jakarta : Rineka Cipta.

Featherstone, M. 2001. Postmodernisme dan Budaya Konsumsi. Yogyakarta: Pustaka Pelajar.

Gardner, Margo and Steinberg, Laurence. 2005. "Peer Influence on Risk Taking, Risk Preference, and Risky Decision Making in Adolescence and Adulthood: An Experimental Study". Temple University. Developental Psychology. 2005. Vol. 41, No. 4, 625-635

Geckova, A. M., Steward, R., Van Diljk, J. P., Orosova, O., Groothoff, J.W., Post, D. 2005. "Influence of Socio-Economic Status, Parents and Peers on Smoking Behaviour of Adolescents". Eur Addict Res 2005; 11: 204209.

Hadija, Lisa. 2013. "Pengaruh Teman Sebaya dan Prestasi Belajar Ekonomi Pada Perilaku Konsumsi Siswa SMA Khadijah Surabaya". JurnalEkonomi Pendidikan dan Kewirausahaan. Vol. 1 No. 2.

Hamalik, Oemar. 2008. Dasar-Dasar Pengembangan Kurikulum. Bandung: PT. Remaja Rosda Karya.

Harari, Tali T. \& Hornik, Jacob. 2010. "Factors Influencing Product Involvement Among Young Consumers". Journal of Consumer Marketing. Volume $27 \cdot$ Number $6 \cdot 2010 \cdot 499-506$.

Haryono, A. 2008. "Pengaruh Proses Pembelajaran, Penilaian Hasil Belajar dan Status Sosial Ekonomi terhadap Tingkat Economic Literacy Siswa SMA di Kota Malang” Disertasi Malang : PPS UM 
Hoyer, Wayne D \& MacInnis, Deborah J. 2008. Consumer Behavior. $5^{\text {th }}$ Edition. Canada: Cengage Learning.

Ioanas, E. \& Stoica, I. 2014. "Social Media and its Impact on Consumers Behavior". International Journal of Economic Practices and Theories, Vol. 4, No. 2, 2014.

Kustiandi, J. 2011. Beberapa Kajian Teori Kawasan Pendidikan Ekonomi. Malang PPS UM.

Kotler, P \& Amstrong, G. 2006. Principle of Marketing. 14 ${ }^{\text {th }}$ edition. New Jersey: Prentice-Hall, Inc.

Kotler, Philip.2007. Manajemen Pemasaran, Analisis Perencanaan, Pengendalian. Prentice Hall, Edisi Bahasa Indonesia, Jakarta: Salemba Empat

Laursen, E. 2005. "Rather Than Fixing Kids-Build Positive Peer Cultures. Reclaiming Children And Youth." Proquest Education Journal. 14. 3. 137-142.

Mangkunegara, A.A. Anwar Prabu. 1988. Perilaku Konsumen. Bandung : Remaja Rosda Karya.

Mappiare, A. 1982. Psikologi Remaja. Surabaya: Usaha Nasional.

Mathews, L. G. 1999. "Promoting economic literacy: ideas for your classroom". Paperprepared for the 1999 AAEA annual meeting Nashville, Tennessee

Monks, F.J., Knoers, A.M.P. \& Haditono, S.R. 2000. Psikologi Perkembangan : Pengantar dalam berbagai bagiannya. Yogyakarta: Gajah Mada University Press.

Mowen, J.C \& M.Minor. 2002. Perilaku Konsumen. Edisi ke 5, jilid 1. Jakarta: Penerbit Erlangga.

Mulyasa, E. 2008. Implementasi Kurikulum 2004 Panduan Pembelajaran KBK. Remaja, Rosdakarya. Bandung

Mercan, N., Kahya, V., Alamur, B. 2014. "A Research regarding to relationship between economic literacy and Consumer Preferences in Knowledge Economy". European Journal of Research on Education, 2014. 2Special Issue 6, 1-13

National Council on Economic Education. 2005. Compaign for economic literacy: Test Your Own Economic Literacy. (http://www.ncee.net/cel/test), diakses 12 Desember 2014.

Ormrod, Jeanne. Ellis. 2008. Educational Psychology Developing Learners Sixth Edition (Psikologi Pendidikan Jilid 2 Edisi ke 6). Alih Bahasa: Amitya Kumara. Jakarta: Erlangga 
Peter, J. Paul \& Olson, Jerry C. (2010). Consumer Behavior \& Marketing Strategy. $9^{\text {th }}:$ McGraw-edition. New York Hill/Irwi

Poerwodarminto. 1990. Kamus Besar Bahasa Indinesia. Jakarta: Balai Pustaka.

Porter, Burton F. 1988. Reason of Living - A Basic Ethics. Russell Sage College. ISBN-10; 0023960507 ISBN-13; 9780023960505. 1988. Pearson. Paper.

Prasastianta, D. E. 2011. Pengaruh Minat Pada Pelajaran Ekonomi, Status Sosial Ekonomi Orang Tua, Pengetahuan Ekonomi Dan Rasionalitas Ekonomi Terhadap Perilaku Ekonomi. Malang: UNM

Prijana, 2005. Metode Sampling Terapan untuk Penelitian Sosial. Humaniora. Bandung.

Purwati, Ana. 2011. "Pengaruh status sosial ekonomi orang tua, persepsi atas lingkungan, dan prestasi belajar ekonomi terhadap perilaku konsumsi". Jurnal Ekonomi Bisnis, Th. 16, No. 1, Maret 201114 Februari 2014

Raharjo, Bambang Puji. 2008. Panduan Belajar Ekonomi. Yogyakarta: Lembaga Pendidikan Primagama.

Riduwan. 2007. Skala Pengukuran Variabel-variabel Penelitian. Bandung: Afabeth

Riduwan. 2012. Dasar-Dasar Statistika. Cetakan kesepuluh. Bandung: Alfabeta

Robbins, Stephen P. dan Judge, Timpthy A. 2008. Perilaku Organisasi. Edisi 12. Jakarta: Salemba Empat.

Rusman. 2012. Model-model Pembelajaran. Depok : PT Rajagrafindo Persada

Ryan, A.M. 2001. "The Peer Group as a Context for the Development of Young Adolescent Motivation and Achievement". Journal of Child Development, 72 4: 1135-1150.

Salemi, Michael K. 2005. "Teaching Economic Literacy: Why, What and How". International Review of Economics Education, Volume 4, issue 2 (2005), pp. 46-57

Samuelson, Paul A. \& Nordhaus, William D. 2000. Mikroekonomi. Jakarta : Erlangga

Santrock, John. 2002. Life-Span Development (Perkembangan Masa Hidup Jilid 1 Edisi Ke 5). Alih Bahasa: Juda Damanik, Achmad Chusairi. Jakarta: Erlangga

Santrock, J.W. 2003. Perkembangan Remaja. Jakarta: Erlangga

Santrock, J. W. 2007. Psikologi Perkembangan. Edisi 11 Jilid 1. Jakarta : Erlangga 
Sarwono, Sarlito Wirawan. 2001. Psikologi Remaja. Jakarta: Raja Grafindo Persada.

Shaffer, David R. 2005. Social and Personality Deveopment. USA : Thompson.

Schiffman, L.G. \& Kanuk, L.L. 2008. Perilaku Konsumen. Edisi ke-7. Jakarta : PT Indeks.

Sina, Peter Garlans. 2012. “Analisis Literasi Ekonomi”. Jurnal Economia. Volume 8. Nomor 2.

Sukiman. 2012. Pengembangan Media Pembelajaran. Yogyakarta : Pustaka Insan Madani.

Sukirno, Sadono. 2002. Pengantar Teori Mikroekonomi. Jakarta : Raja Grafindo Persada.

Sukirno, Sadono. 2014. Mikroekonomi Teori Pengantar. Edisi Ketiga. Jakarta : Raja Grafindo Persada.

Sukmadinata, N.S. 2007. Landasan Psikologi Proses Pendidikan. Bandung : Remaja Rosdakarya.

Suwatno. 2011. Manajemen Sumber Daya Manusia. Bandung : Alfabeta.

Tirtahardja, Umar dan La Sula. 2005. Pengantar Pendidikan. Jakarta: PT. Rineka Cipta

Umar, Husein. 2003. Metodologi Penelitian untuk Skripsi dan Tesis Bisnis. Jakarta : PT Gramedia Pustaka

Wahyuni, T. Endang. 2011. Faktor-faktor yang Mempengaruhi Perilaku Konsumsi Mahasiswa Fakultas Ekonomi Universitas PGRI Yogyakarta. [Online]. Vol. 2. No. 3. Desember 2011. 12 Halaman. Tersedia : http://www.scribd.com/doc/14339457/Faktor-faktor-yangMempengaruhi-Konsumsi-Mahasiswa-Fakultas-Ekonomi-UniversitasPGRI-Yogyakarta.19

Walgito, Bimo 1994. Psikologi Sosial. Yogyakarta: Andi Offset

Wibowo. 2013. Perilaku Dalam Organisasi. Jakarta : Raja Grafindo Persada

Willis, S.S. 2005. Remaja \& Masalahnya: Mengupas Berbagai Bentuk Kenakalan Remaja, Narkoba, Free Sex dan Pemecahannya. CV Alfabeta: Bandung.

Wirawan, Yahya R. 2015. Pengaruh Status Sosial Ekonomi OrangTua terhadap Prestasi Belajar Ekonomi dan Perilaku Konsumsi Siswa SMA Negeri 01 Kota Jombang. Tesis. Surabaya : Unesa

Wulandari. 2011. "Hanya 42,6 Persen Guru Ekonomi Berkualitas Baik". Republika. Edisi 3 April 2011 
Yanti, S, Maksum, J.H. , Asriati, N. 2014. Pengaruh penguasaan konsep ekonomi dan status sosial ekonomi orang tua terhadap pola perilaku konsumsi siswa Tesis magister pendidikan ekonomi tidak dipublikasikan Universitas Tanjungpura Pontianak.

Yunus, N. K. Y, Ishak, S. \& Jalil, N. A. 2010. "Economic Literacy amongst the Secondary School Teachers in Perak Malaysia". Information Management and Business ReviewVol. 1, No.2, pp. 69-78, Dec. 2010. 